\title{
A Parameter Study of Solid Oxide Electrolysis Cell Degradation: Microstructural Changes of the Fuel Electrode
}

Michael Philipp Hoerlein, ${ }^{\mathrm{a}}$ Matthias Riegraf,, ${ }^{\mathrm{a},}{ }^{,}$Rémi Costa, ${ }^{\mathrm{a}}$ Günter Schiller, ${ }^{\mathrm{a}}$ K. Andreas Friedrich $^{\mathrm{a}, \mathrm{b}}$

${ }^{a}$ German Aerospace Centre (DLR), Institute of Engineering Thermodynamics, Pfaffenwaldring 38-40, 70569 Stuttgart, Germany

${ }^{\mathrm{b}}$ University of Stuttgart, Institute of Energy Storage, Pfaffenwaldring 31, 70569 Stuttgart, Germany

*Corresponding author: E-mail: Matthias.Riegraf@dlr.de, Phone: +49 (0) 711 6862-8027, Fax: $+49(0) 7116862-747$

Keywords: Solid oxide electrolysis cell (SOEC), Ni/YSZ electrode, Degradation, Electrochemical impedance spectroscopy, Ni depletion 


\begin{abstract}
A parameter study of 20 solid oxide electrolysis cells was carried out to systematically investigate long-term degradation each over $1,000 \mathrm{~h}$ under variation of temperature, humidity and current density. The influence of operating temperature was investigated between 750 and $850{ }^{\circ} \mathrm{C}$, the humidity ranged from $40 \%$ to $80 \% \mathrm{H}_{2} \mathrm{O}$, and the current density varied between open circuit voltage $(\mathrm{OCV})$ and $1.5 \mathrm{~A} \cdot \mathrm{cm}^{-2}$. The progress of degradation was monitored insitu by electrochemical impedance spectroscopy. Five different contributions to the spectra were identified by calculating the distribution of relaxation times and separated via a complex non-linear square fitting routine. The present work focuses on the degradation of the fuel electrode. From SEM analysis, Ni depletion and an increased pore fraction close to the electrode/electrolyte interface was derived, which is correlated with an increased ohmic resistance of the cells. This unidirectional transport of $\mathrm{Ni}$ away from the fuel electrode/electrolyte interface leads to an effective electrolyte extension and is the main source of degradation. Ni depletion is shown to be driven by current density and its extent is shown to be dependent on the complex interplay between the operating parameters current density, anode overpotential, humidity and temperature. It is particularly pronounced for $p \mathrm{H}_{2} \mathrm{O}$ larger than $0.8 \mathrm{~atm}$ and temperatures above $800{ }^{\circ} \mathrm{C}$. Furthermore, the fuel electrode electrochemistry also exhibits degradation in the high-frequency region around $10^{4} \mathrm{~Hz}$.
\end{abstract}




\section{Introduction}

The transition to a more renewable electricity generation is accompanied by the challenge of an increasing mismatch between production and demand, which leads to a growing electric energy storage demand. In this regard, the solid oxide electrolysis cell (SOEC) promises high efficiencies towards the conversion of water into hydrogen and is therefore considered particularly environmentally friendly. However, especially at high current densities degradation limits its lifetime thus hindering commercialization. Several degradation processes on both fuel and air electrode have been identified and investigated.[1,2]

On the fuel electrode, one common degradation phenomenon in SOEC is the segregation of impurities such as silica at the triple phase boundary (TPB). $[3,4]$ Impurities can partially be removed by reversible operation in SOFC mode.[5] Furthermore, Ni agglomeration is a common degradation phenomenon in Ni/YSZ electrodes of solid oxide cells operating at high fuel gas humidity, which leads to a reduction in TPB length.[6-9] This is partially due to a minimization of free surface energy according to Ostwald ripening but can also be correlated to a high $\mathrm{Ni}$ mobility due to $\mathrm{Ni}(\mathrm{OH})_{\mathrm{x}}$ formation. $[7,8,10,11]$ At high current densities and large overpotentials Ni relocation has been shown to lead to irreversible Ni migration away from the electrolyte and to $\mathrm{Ni}$ depletion of the most inner few micrometers close to the electrolyte.[10-13] This leads to the shift of the reaction zone away from the electrolyte and essentially represents an effective extension of the electrolyte. At a higher temperature of 950 ${ }^{\circ} \mathrm{C}$, the Ni migration has been observed to be directed towards the electrolyte and has led to a clogging of the pores close to the electrolyte.[7] Furthermore, Ni depletion at the fuel electrode/electrolyte interface has also been observed in solid oxide fuel cell operation, possibly driven by a similar mechanism. [6,14,15] Recently, this process was suggested to be driven by potential and humidity gradients.[10] However, the underlying mechanism is still not fully understood. 
Despite the increasing progress achieved in the identification and mitigation of degradation processes, a systematic investigation of the influence of key operating parameters on the extent of degradation is still missing. In the present work, SOEC degradation of 20 state-ofthe-art LSCF $|\mathrm{CGO}| \mathrm{YSZ} \mid \mathrm{Ni} / \mathrm{YSZ}$ fuel cells is systematically analyzed during $1,000 \mathrm{~h}$ testing in order to establish a clear correlation between degradation processes and operating conditions. Three parameters, namely the operating temperature, the current density and the fuel gas humidity, were identified to be most revealing and the experimental matrix shown in Fig. 1 was devised to separately identify the influence of each parameter and gain insights into the nature and extent of the occurring degradation processes. This work mainly focuses on the microstructural changes of the fuel electrode. The degradation of the other cell components will be published elsewhere.

\section{Experimental}

In the present work, commercially available anode-supported fuel cells (ASC) supplied by CeramTec (Marktredwitz, Germany) were used. They are supported by a $290 \mu \mathrm{m}$ fuel electrode layer, which is a composite of $\mathrm{Ni}$ and $8 \mathrm{YSZ}$ produced by warm pressing using a socalled Coat-Mix material and pre-sintered at $1230{ }^{\circ} \mathrm{C}$. The active electrode of the cells consisted of a porous composite with an $8-10 \mu \mathrm{m}$ thick Ni/YSZ active layer. The electrolyte was a tape-casted $8 \mathrm{YSZ}$ layer with a thickness of $10 \mu \mathrm{m}$ sintered at $1230^{\circ} \mathrm{C}$. The air electrode consisted of $30 \mu \mathrm{m}$ thick $\mathrm{La}_{0.6} \mathrm{Sr}_{0.4} \mathrm{Co}_{0.2} \mathrm{Fe}_{0.8} \mathrm{O}_{3-\delta}$ (LSCF-6428). In addition a $3-4 \mu \mathrm{m}$ thick screen-printed GCO diffusion barrier layer was employed to reduce reactivity between the 8YSZ electrolyte and the LSCF-6428 oxygen electrode. The active area of the planar cells was $4 \times 4 \mathrm{~cm}^{2}$ with a total area of $5 \times 5 \mathrm{~cm}^{2}$. The setup for cell testing enables the characterization of up to four cells simultaneously and was already illustrated and described in a similar configuration in detail elsewhere.[16,17] 
Anode and cathode were contacted with nickel and platinum meshes, respectively, and gold was used as the sealant between the anode and the cathode side, thus avoiding the use of silica-containing materials. In all tests, cells were operated at a constant total fuel flow rate of 2 SLPM (standard liter per minute) for each cell. The air electrode was operated with air at a constant flow rate of 2 SLPM. These large flow rates were chosen to keep gas conversion below $20 \%$ for all degradation measurements thus reducing gradients across the length of the cell and consequently minimizing the emergence of local degradation effects. The fuel gas humidification was implemented with a "Controlled Evaporator Mixer" (CEM) in combination with a liquid water mass flow controller (Cori-Flow ${ }^{\mathrm{TM}}$, Bronkhorst, Netherlands).

The cells were heated $(3 \mathrm{~K} / \mathrm{min})$ to $900{ }^{\circ} \mathrm{C}$ and reduced. The $\mathrm{OCV}$ was checked before starting the tests and confirmed to be higher than $1.20 \mathrm{~V}$ at $900{ }^{\circ} \mathrm{C}$ in pure hydrogen and air (each 1 SLPM) for all investigated cells, assuring proper gas tightness. Consecutively, the operating temperature was changed to $800{ }^{\circ} \mathrm{C}$ and initial characterization was carried out with a polarization curve in fuel cell mode with a $\mathrm{H}_{2} / \mathrm{H}_{2} \mathrm{O}(96 / 4)$ mixture. Subsequently, electrochemical impedance spectroscopy (EIS) measurements were conducted with $4 \% \mathrm{H}_{2} \mathrm{O}$ at $\mathrm{OCV}$ and $60 \% \mathrm{H}_{2} \mathrm{O}$ at $\mathrm{OCV}$ and $-0.5 \mathrm{~A} \cdot \mathrm{cm}^{-2}$, respectively, in order to characterize the initial state of the cells. After this initial characterization the degradation experiment was started. During the experiments, the current of all cells was interrupted approximately every $168 \mathrm{~h}$ (weekly) for intermediate cell characterizations. In order to gain comparable data humidification and temperature were adjusted to $60 \%$ molar humidity $(\mathrm{MH})$ and $800{ }^{\circ} \mathrm{C}$, respectively for all impedance spectroscopy measurements. These were conducted at $-0.5 \mathrm{~A} \cdot \mathrm{cm}^{-2}$. After the impedance measurements, the operating conditions were applied again and the degradation measurement was continued. At the end of the degradation experiment after approximately $1000 \mathrm{~h}$ a final characterization was carried out before the cells were cooled down. Besides the investigated parameters all other parameters were kept 
constant for all degradation measurements. Furthermore, deviations between the respective measurements were minimized by conducting all experiments in the same test rig and using commercially available, highly reproducible cells of the same batch. A fresh cell was used for each of the 20 parameter combinations displayed in Fig. 1.

For electrochemical impedance spectroscopy measurements, an electrochemical workstation (Zahner ${ }^{\circledR}$ PP-240 with Thales software) was used in a typical frequency range from $500 \mathrm{mHz}$ to $100 \mathrm{kHz}$. The amplitude of the current stimulus was $500 \mathrm{~mA}$ and chosen in order to achieve a voltage response not higher than $10 \mathrm{mV}$. A representative example for a fitted spectrum is depicted in Fig. A.1, where values for fitting error as well as uncertainty of each fitting parameter are presented.

The distribution of relaxation times (DRT) was calculated with a modified LevenbergMarquardt algorithm adapted from Ref.[18] SEM images were recorded with a Zeiss Ultra Plus SEM (Oberkochen, Germany). In order to separate percolated from non-percolated Ni, measurements at low acceleration voltage were conducted without prior carbon deposition, according to the procedure in Ref.[19].

\section{Results and Discussion}

\section{Initial cell characterization}

Initially recorded current-voltage characteristics of one of the cells in fuel cell mode are exemplarily depicted in Fig. A. $2\left(800{ }^{\circ} \mathrm{C}, 96 / 4 \mathrm{H}_{2} / \mathrm{H}_{2} \mathrm{O}\right.$, air $)$. At $1.5 \mathrm{~A} \cdot \mathrm{cm}^{-2}$ the cell voltage is still at $0.73 \mathrm{~V}$, demonstrating the cell's high performance.

To separate the occurring processes and obtain information about their characteristic frequencies, the DRT was calculated. A typical DRT plot of a cell in its initial state measured at $800{ }^{\circ} \mathrm{C}$ and $60 \% \mathrm{MH}$ is presented in Fig. A.3. Including the ohmic resistance, it shows the existence of five rate-limiting processes. Their characteristic frequencies are approximately 
one order of magnitude apart and are roughly at $2 \cdot 10^{4}, 10^{3}, 10^{2}$ and $10 \mathrm{~Hz}$, respectively. Based on a variation of operating parameters (temperature $T$, oxygen partial pressure on the air electrode side $p \mathrm{O}_{2}$, and humidity on the fuel electrode side $p \mathrm{H}_{2} \mathrm{O}$; not shown here) and analogies to previous EIS studies,[20-24] their physical origins were assigned to the following processes: the two high frequency peaks $\left(\sim 10^{3}\right.$ and $\left.2 \cdot 10^{4} \mathrm{~Hz}\right)$ are related to the coupled fuel electrode charge transfer reaction and ionic conduction within porous ceramic matrix, the medium frequency peak $\left(\sim 10^{2} \mathrm{~Hz}\right)$ represents the charge transfer coupled with the ionic transport within the oxygen electrode and the low frequency peak $(\sim 10 \mathrm{~Hz})$ corresponds to the gas transport limitation at the fuel electrode.

These insights lead to the development of the equivalent circuit model (ECM) presented in Fig. 2, which was used for separation of the different processes and their quantification. Both fuel electrode processes are represented by R-CPE (constant phase element with exponent of 0.9) elements. The oxygen electrode process $P_{3}$ is characterized by a closed Gerischer element.[25-27] The gas transport limitation $\mathrm{P}_{4}$ is modeled by an R-C-element. In previous studies of the cells in the same test bench (not shown here), the gas transport limitation was shown to be dominated by gas conversion. Therefore, this process is not characterized by a Warburg Element as commonly used in literature for the modeling of porous gas diffusion. Additionally, a serial resistance is modeled by a resistor element $\mathrm{P}_{0}$ which mainly represents the ionic resistance of the electrolyte but also contains a contribution of the GDC layer between electrolyte and LSCF cathode and contact resistances. An inductive element L compensates for inductive interference. A list of these processes with their physico-chemical origins is depicted in Table 1. Furthermore, the average characteristic frequencies and initial resistance values of the respective processes are shown. Reproducibility of the cells during the initial impedance characterization can be deduced from the standard deviations given in Table 1 and is also demonstrated in the Nyquist plot in Fig. 3 that depicts the initial spectra of 
four different cells and shows only minor deviations. Moreover, the contributions of the different separated processes to the overall resistance are indicated in the graph.

Table 1. Processes considered for quantification, their respective physical interpretation, initial characteristic frequency and typical initial resistance at $800{ }^{\circ} \mathrm{C}, 60 \% \mathrm{MH}$ and -0.5 $\mathrm{A} \cdot \mathrm{cm}^{-2}$

\begin{tabular}{|c|c|c|c|c|}
\hline $\begin{array}{l}\text { Process } \\
\text { notation }\end{array}$ & Physical interpretation & $\begin{array}{l}\text { Characteristic } \\
\text { frequency / Hz }\end{array}$ & $\begin{array}{l}\text { Average initial } \\
\text { value }\end{array}$ & $\begin{array}{l}\text { Standard- } \\
\text { deviation / } \\
\mathrm{m} \Omega \cdot \mathrm{cm}^{2}\end{array}$ \\
\hline $\mathrm{L}$ & Inductive interference & - & $1-10 \mathrm{nH}$ & \\
\hline$\overline{\mathrm{P}_{0}}$ & $\begin{array}{l}\text { Ohmic resistance through } \\
\text { electrolyte and CGO barrier } \\
\text { layer, contact resistance }\end{array}$ & - & $114 \mathrm{~m} \Omega \cdot \mathrm{cm}^{2}$ & 2.1 \\
\hline$\overline{P_{1}}$ & $\begin{array}{l}\text { Fuel electrode ionic transport } \\
\text { coupled with charge transfer } \\
\text { reaction }\end{array}$ & $2 \cdot 10^{4}$ & $29 \mathrm{~m} \Omega \cdot \mathrm{cm}^{2}$ & 2.9 \\
\hline $\mathrm{P}_{2}$ & $\begin{array}{l}\text { Fuel electrode charge transfer } \\
\text { reaction }\end{array}$ & $10^{3}$ & $34 \mathrm{~m} \Omega \cdot \mathrm{cm}^{2}$ & 2.6 \\
\hline$\overline{P_{3}}$ & $\begin{array}{l}\text { Oxygen electrode charge transfer } \\
\text { and ionic transport }\end{array}$ & $10^{2}$ & $11 \mathrm{~m} \Omega \cdot \mathrm{cm}^{2}$ & 0.5 \\
\hline $\mathrm{P}_{4}$ & Fuel electrode gas transport & $10^{1}$ & $17.5 \mathrm{~m} \Omega \cdot \mathrm{cm}^{2}$ & 0.7 \\
\hline
\end{tabular}

\section{Long-term degradation study}

In this section, degradation of the fuel electrode processes and the fuel electrode-related degradation of the ohmic resistance are addressed. First, the ohmic resistance change caused by microstructural changes in the fuel electrode functional layer is investigated. Then, the 
degradation of the processes related to the electrochemical steam reduction on the fuel electrode is examined.

Figure 4 shows the evolution of cell voltage over time of all cells. In all five long-term tests a more pronounced voltage degradation can be observed for increasing current densities. For cells operated at $750{ }^{\circ} \mathrm{C}$ and $80 \%$ humidity, it is worth noticing that the increase in current density from $1.0 \mathrm{~A} \cdot \mathrm{cm}^{-2}$ to $1.5 \mathrm{~A} \cdot \mathrm{cm}^{-2}$ results in a smaller than expected voltage step. Additionally, the cells operated at $1.0 \mathrm{~A} \cdot \mathrm{cm}^{-2}$ and $1.5 \mathrm{~A} \cdot \mathrm{cm}^{-2}$ show a comparable voltage degradation after the transient phase. This phenomenon is not an experimental artifact and cannot be explained on the light of the experimental data obtained in the present study. However, this is not affecting the conclusions of the present study.

Comparison of the processes' resistance evolution as extracted from EIS data gives more detailed insights into the cells' degradation behavior.[28] The results of the corresponding electrochemical measurements are shown in the following subsection and subsequently correlated with post mortem SEM findings.

\subsection{Ohmic resistance}

\subsubsection{Electrochemical measurements}

Fig. 5 shows an overview of the evolution of the ohmic resistance for all 20 cells investigated in the five long-term experiments. In Table 2, the increase of ohmic resistance after $1000 \mathrm{~h}$ is summarized for all cells, based on the individual initial resistance of each cell.

Table 2. Overview of the change of ohmic resistance after $1000 \mathrm{~h}$ for all 20 long-term tests.

\begin{tabular}{|c|c|c|c|c|c|}
\hline & $\begin{array}{c}R_{\mathrm{ohm}} \\
800{ }^{\circ} \mathrm{C}, 40 \% \\
{\left[\mathrm{~m} \Omega \cdot \mathrm{cm}^{2}\right]}\end{array}$ & $\begin{array}{c}R_{\mathrm{ohm}} \\
800{ }^{\circ} \mathrm{C}, 60 \% \\
{\left[\mathrm{~m} \Omega \cdot \mathrm{cm}^{2}\right]}\end{array}$ & $\begin{array}{c}R_{\mathrm{ohm}} \\
800{ }^{\circ} \mathrm{C}, 80 \% \\
{\left[\mathrm{~m} \Omega \cdot \mathrm{cm}^{2}\right]}\end{array}$ & $\begin{array}{c}R_{\mathrm{ohm}} \\
750{ }^{\circ} \mathrm{C}, 80 \% \\
{\left[\mathrm{~m} \Omega \cdot \mathrm{cm}^{2}\right]}\end{array}$ & $\begin{array}{c}R_{\mathrm{ohm}} \\
850{ }^{\circ} \mathrm{C}, 80 \% \\
{\left[\mathrm{~m} \Omega \cdot \mathrm{cm}^{2}\right]}\end{array}$ \\
\hline OCV & 28 & 30 & 27 & 38 & 16 \\
\hline
\end{tabular}




\begin{tabular}{|c|c|c|c|c|c|}
\hline $0.5 \mathrm{~A} \cdot \mathrm{cm}^{-2}$ & 27 & 31 & 41 & 50 & 21 \\
\hline $1 \mathrm{~A} \cdot \mathrm{cm}^{-2}$ & 31 & 31 & 59 & 54 & 39 \\
\hline $1.5 \mathrm{~A} \cdot \mathrm{cm}^{-2}$ & 43 & 38 & 87 & 48 & 76 \\
\hline
\end{tabular}

Cells operated at $40 \% \mathrm{MH}$ and $60 \% \mathrm{MH}$ show a very similar behavior, indicating that humidity has no effect on ohmic degradation in this range. At $80 \% \mathrm{MH}$, however, a significant impact can be observed. While cells operated at OCV show an almost identical resistance increase at 40,60 and $80 \% \mathrm{MH}$, the effect of humidity increases with increasing current density. At $1.5 \mathrm{~A} \cdot \mathrm{cm}^{-2}$ the degradation of the ohmic resistance of the cell operated at $80 \% \mathrm{MH}$ is roughly twice as large compared to the cell operated at 40 and $60 \% \mathrm{MH}$.

A clear trend with temperature can be observed for cells operated at $\mathrm{OCV}$, where the strongest increase in resistance is measured for the cell operated at $750^{\circ} \mathrm{C}$, while higher temperatures leads to a smaller increase in the resistance. This trend can also be observed for cells operated at $0.5 \mathrm{~A} \cdot \mathrm{cm}^{-2}$. However, at $1.0 \mathrm{~A} \cdot \mathrm{cm}^{-2}$ the degradation of the cell operated at $800{ }^{\circ} \mathrm{C}$ is already slightly larger compared to the cell operated at $750{ }^{\circ} \mathrm{C}$. At $1.5 \mathrm{~A} \cdot \mathrm{cm}^{-2}$ the cells operated at $800^{\circ} \mathrm{C}$ and $850^{\circ} \mathrm{C}$ exhibit a similar degradation which is significantly larger compared to that at $750{ }^{\circ} \mathrm{C}$.

The fact that humidity has no influence on the resistance increase at $\mathrm{OCV}$, along with the observed temperature dependence is an indication that the associated degradation at OCV is not originating from the fuel electrode, as will be substantiated by post mortem analysis later. It is assumed to be mainly dominated by $8 \mathrm{YSZ}$ electrolyte degradation and independent of current.[29] Thus, the impact of the current can be largely isolated by referring to the degradation at OCV as a baseline.

In general, during all tests a more pronounced increase of the ohmic resistance was observed with increasing current densities. At 40 and $60 \% \mathrm{MH}\left(800^{\circ} \mathrm{C}\right)$ the effect of current is very similar where hardly any effect up to $1.0 \mathrm{~A} \cdot \mathrm{cm}^{-2}$ is detectable for both humidities, while a 
small increase at $1.5 \mathrm{~A} \cdot \mathrm{cm}^{-2}$ can be observed. However, at $80 \% \mathrm{MH}$ a clear influence of the current density can be observed, where even the cell operated at $0.5 \mathrm{~A} \cdot \mathrm{cm}^{-2}$, displays an increased ohmic resistance degradation compared to the cell operated at OCV. The extent of this degradation further progresses with increasing current density.

Also at $750{ }^{\circ} \mathrm{C}$ the influence of the current density is comparatively small. While cells operated under current show higher ohmic resistance increase than the cell at OCV, the corresponding values are very similar to each other. Thus, at $750{ }^{\circ} \mathrm{C}$ no clear trend regarding the influence of current density can be identified. At $800{ }^{\circ} \mathrm{C}(80 \% \mathrm{MH})$ and $850{ }^{\circ} \mathrm{C}$, however, a clear correlation between increase in current density and enhanced degradation can be observed. At $800^{\circ} \mathrm{C}$ the impact of current is already pronounced at $0.5 \mathrm{~A} \cdot \mathrm{cm}^{-2}\left(\Delta \mathrm{R}_{\mathrm{ohm}}=41-\right.$ $27=14 \mathrm{~m} \Omega \cdot \mathrm{cm}^{2}$ ) while at $850{ }^{\circ} \mathrm{C}$ there is only a small impact of operating at $0.5 \mathrm{~A} \cdot \mathrm{cm}^{-2}$ $\left(\Delta \mathrm{R}_{\mathrm{ohm}}=21-16=5 \mathrm{~m} \Omega \cdot \mathrm{cm}^{2}\right)$. Nevertheless, at high $1.5 \mathrm{~A} \cdot \mathrm{cm}^{-2}$ the effect of current density on the resistance increase is very similar with $60 \mathrm{~m} \Omega \cdot \mathrm{cm}^{2}$ for both cells operated at 800 and $850^{\circ} \mathrm{C}$. This translates into a disproportional increase in ohmic resistance with current density for both temperatures. At $800{ }^{\circ} \mathrm{C}$ the increase in ohmic resistance is four times larger at $1.5 \mathrm{~A} \cdot \mathrm{cm}^{-2}$ compared to $0.5 \mathrm{~A} \cdot \mathrm{cm}^{-2}$, whereas at $850{ }^{\circ} \mathrm{C}$ it is more than ten times larger.

\subsubsection{Post mortem analysis}

The results of post mortem SEM analysis are presented in the following to identify the nature and location of the observed increase in ohmic resistance. Microstructural changes in the fuel electrode have already been reported and correlated to changes in the ohmic resistance in the past and thus, are extensively investigated in the present study.[10,12,13] Furthermore, electrolyte and cathode layers were examined since pore formation along YSZ grain boundaries close to the electrolyte/oxygen electrode interface as well as air electrode delamination from the electrolyte have been observed on samples aged at high current densities before.[1,11,30-34] However, this could not be observed in the present study. 
Therefore, if any, the impact of such degradation processes in our investigation is expected to remain marginal.

To investigate microstructural changes in the functional fuel electrode layer, particularly the ones related to the Ni phase, low-energy SEM imaging was used. This technique enables distinguishing the percolated from the non-percolated $\mathrm{Ni}$ phase and the ceramic YSZ matrix.[19] The effect of this technique is exemplarily illustrated on a reduced reference sample in Fig. 6.

Furthermore, Fig. 6 displays the influence of the current density by showing SEM images of the electrolyte/fuel electrode interface of the four cells operated at $800{ }^{\circ} \mathrm{C}, 80 \% \mathrm{MH}$ and OCV $, 0.5,1.0$ and $1.5 \mathrm{~A} \cdot \mathrm{cm}^{-2}$. While the SEM image of the cell operated at OCV looks very similar to the one of the reference cell, Ni depleted regions close to the electrolyte become visible with increasing current density. At $0.5 \mathrm{~A} \cdot \mathrm{cm}^{-2}$ this phenomenon is only apparent in certain regions, however, at $1.0 \mathrm{~A} \cdot \mathrm{cm}^{-2}$ and $1.5 \mathrm{~A} \cdot \mathrm{cm}^{-2} \mathrm{Ni}$ depletion occurs on a length scale of $1-2 \mu \mathrm{m}$ along the whole electrolyte/fuel electrode interface, which results in a layer fully depleted of Ni. Fig. 6 also reveals the existence of non-percolated Ni particles. While in cells operated up to $1.0 \mathrm{~A} \cdot \mathrm{cm}^{-2}$ only small amounts can be detected a significantly higher quantity can be found in the cell operated at $1.5 \mathrm{~A} \cdot \mathrm{cm}^{-2}$. The analogue dependence of the Ni depletion process and the increase in ohmic resistance on current density is an indication that the behavior of the ohmic resistance degradation in Fig. 5 is associated to Ni depletion.

Fig. 7 displays how the fuel gas humidity influences Ni depletion. All three cells presented were operated at $800{ }^{\circ} \mathrm{C}$ and high current density, that is, $1.5 \mathrm{~A} \cdot \mathrm{cm}^{-2}$, since current density appears to be a driving force for $\mathrm{Ni}$ depletion. A Ni deprived layer is clearly formed at $80 \% \mathrm{MH}$, while the cells operated at lower humidities do not show Ni depleted areas. An increased number of non-percolated $\mathrm{Ni}$ particles can also only be found for the sample operated at $80 \% \mathrm{MH}$. 
In order to reveal the influence of temperature, Fig. 8 compares cells operated at $750{ }^{\circ} \mathrm{C}$, $800{ }^{\circ} \mathrm{C}$ and $850{ }^{\circ} \mathrm{C}$, at $80 \% \mathrm{MH}$ and $1.5 \mathrm{~A} \cdot \mathrm{cm}^{-2}$. In agreement with the observed influence of temperature on ohmic resistance increase in Fig. 5, a similar extent of Ni depletion can be observed at 800 and $850{ }^{\circ} \mathrm{C}$. At $750{ }^{\circ} \mathrm{C}$ significantly less pronounced Ni depletion was found. For this cell, certain areas at the electrolyte/fuel electrode interface were depleted of $\mathrm{Ni}$, however, no Ni-vacated layer was formed. Only for the cell operated at $800^{\circ} \mathrm{C}$ an increased number of non-percolated Ni particles can be found, while the cells operated at 750 and $850^{\circ} \mathrm{C}$ do not exhibit this increase.

Cells operated at OCV display a very similar Ni distribution compared to the reference cell. Therefore, the increase of the ohmic resistance of the cells operated at OCV is not caused by Ni depletion but can be assumed to have its origin in electrolyte degradation. It is expected to occur at the same rate for cells at the same temperature, as confirmed by the values at $800{ }^{\circ} \mathrm{C}$ in Table 2.[29] Furthermore, resistance increase at low humidities (40\% $\mathrm{MH}$ and $60 \% \mathrm{MH})$, where no indication of Ni-depletion can be found by SEM imaging, behaves almost independently of current, suggesting the electrolyte degradation being independent of the applied current.

To assess the magnitude of the ohmic resistance increase due to Ni depletion, its additional resistance is estimated for the cell operated at $800{ }^{\circ} \mathrm{C}, 80 \% \mathrm{MH}$ and $1.5 \mathrm{~A} \cdot \mathrm{cm}^{-2}$. In this case the Ni-depleted layer is approximately $2 \mu \mathrm{m}$ thick. The equivalent thickness of this layer $d_{\text {eff }}$ is then calculated according to

$$
d_{\mathrm{eff}}=d_{\mathrm{Ni}, \mathrm{depl}} \frac{\tau}{\varepsilon},
$$

with porosity $\varepsilon$ estimated to be 0.37 and tortuosity $\tau$ being 2 [35-38] which leads to a value of $10.8 \mu \mathrm{m}$. Typical values of $50 \Omega \cdot \mathrm{cm}$ to $60 \Omega \cdot \mathrm{cm}$ are reported for $8 \mathrm{YSZ}$ resistivity at $800{ }^{\circ} \mathrm{C}$, which suggests that the YSZ electrolyte $\left(d_{\mathrm{YSZ}}=10 \mu \mathrm{m}\right)$ accounts for an ohmic resistance of $55 \mathrm{~m} \Omega \cdot \mathrm{cm}^{2}$ and, therefore, approximately $50 \%\left(55 \mathrm{~m} \Omega \cdot \mathrm{cm}^{2} / 114 \mathrm{~m} \Omega \cdot \mathrm{cm}^{2}\right)$ of the total ohmic 
resistance of the tested cells.[39,40] With this value, the additional resistance of the Nidepleted layer $R_{\text {eff }}$ amounts to

$$
R_{\mathrm{eff}}=R_{Y S Z} \frac{d_{\mathrm{eff}}}{d_{\mathrm{YSZ}}}=59 \mathrm{~m} \Omega \cdot \mathrm{cm}^{2}
$$

This value is in good agreement with the measured change of the ohmic resistance attributed to Ni depletion $\left(\Delta \mathrm{R}_{\mathrm{ohm}}=87 \mathrm{~m} \Omega \cdot \mathrm{cm}^{2}-27 \mathrm{~m} \Omega \cdot \mathrm{cm}^{2}=60 \mathrm{~m} \Omega \cdot \mathrm{cm}^{2}\right)$.

The above results show a strong correlation between the Ni depletion observed by SEM imaging and an increase in ohmic resistance. The influence of all three investigated operating parameters on Ni depletion was found to correlate with the increase in ohmic resistance. Furthermore, the calculated impact of the Ni depleted layer is in good agreement with the measured ohmic degradation (subtracted by the base degradation attributed to the other cell components). These findings strongly suggest that $\mathrm{Ni}$ depletion in the active fuel electrode is one of the major processes responsible for SOEC degradation. The established quantitative correlation between microstructural and electrochemical degradation might possibly be used for predicting the effect of $\mathrm{Ni}$ depletion on electrochemical degradation, once a detailed understanding of the Ni depletion mechanism and its kinetics are established.

\subsubsection{Discussion of the mechanism}

The observed Ni depletion in the anode functional layer is probably caused by a Ni diffusion process, either in the solid state or in the gas phase as evaporated $\mathrm{Ni}$ species. In general, possible drivers of these diffusion processes could be a gradient in gas composition, the potential gradient perpendicular to the electrode/electrolyte interface within the porous electrode as well as a gradient in temperature. In the following, several possible mechanisms are discussed.

$\mathrm{Ni}$ depletion of Ni-based fuel electrodes has been observed before in both SOEC and SOFC mode at high current densities/large overpotentials and was related to the evaporation of $\mathrm{Ni}$ 
particles via $\mathrm{Ni}(\mathrm{OH})_{\mathrm{x}}$ formation.[6,7,10,12,13,15] According to this theory, a gradient in the activity of volatile $\mathrm{Ni}(\mathrm{OH})_{\mathrm{x}}$ must be the driving force of such a process.

During SOEC operation, steam is reduced to hydrogen at the electrode and therefore conditions are increasingly reducing closer to the electrolyte. Since the transport of Ni via volatile species occurs along the concentration gradient towards more reducing conditions, $\mathrm{Ni}$ should be transported towards the electrolyte. This behavior was indeed observed by Hauch et al. for cells operated at high current densities $\left(2 \mathrm{~A} \cdot \mathrm{cm}^{-2}\right.$ in SOEC mode) and $950{ }^{\circ} \mathrm{C}$.[7] However, the present study shows transport away from the electrolyte, which is consistent with other studies at operating temperatures of $850^{\circ} \mathrm{C}$ or lower. $[10,12,13]$ Consequently, the gas concentration gradient cannot be the reason for Ni depletion observed in the present study. Another possible explanation for a gradient in $\mathrm{Ni}(\mathrm{OH})_{\mathrm{x}}$ activity could be caused by a difference in the polarization of Ni particles. This was recently used by Mogensen et al. to formulate a Ni depletion mechanism in SOEC mode.[10] Due to high electronic conductivity of $\mathrm{Ni}$, Ni particles within the percolation network display nearly identical electrostatic potential. Relative to the negatively polarized Ni percolation network the non-percolated Ni particles exhibit a significantly more positive potential. This, in turn, leads to a more favorable oxidation of the $\mathrm{Ni}$ particles to volatile $\mathrm{Ni}(\mathrm{OH})_{\mathrm{x}}$ species and their transport away from the electrolyte.

It is difficult to assess how operating parameters influence the formation of isolated $\mathrm{Ni}$ particles due to insufficient knowledge about the mechanisms and kinetics of the underlying processes. Significantly increased amounts of non-percolated Ni could only be observed for the cell operated at $1.5 \mathrm{~A} \cdot \mathrm{cm}^{-2}, 800{ }^{\circ} \mathrm{C}$ and $80 \% \mathrm{MH}$. Consequently no clear dependence of the investigated parameters on the formation of non-percolated $\mathrm{Ni}$ particles can be derived. The fact that there are cells with $\mathrm{Ni}$ depleted layers but no significant amount of nonpercolated Ni particles could be explained if the loss of percolation is the rate limiting step for Ni depletion at these conditions. It could also indicate that it is not the loss of percolation and 
the accompanying gradient in polarization which is responsible for Ni depletion. However, the present data does not allow for a clear statement.

In Fig. 9 gap formation between the Ni and YSZ phase is investigated. Fig. 9a shows a SEM image by Hauch et al. that illustrates the loss of contact between Ni and YSZ phase. However, an exemplary SEM image of one of our cells operated under similar operating conditions in Fig. $9 \mathrm{~b}$ depicts no visible similar gap formation. The absence of visible Ni-YSZ contact loss was confirmed by SEM analysis of all other cells examined in this study (not shown here). These results question whether the Ni-YSZ contact loss is indeed a prerequisite for the proposed mechanism of $\mathrm{Ni}$ depletion, or if the loss of Ni percolation is sufficient to trigger the $\mathrm{Ni}(\mathrm{OH})_{\mathrm{x}}$ formation process. However, such a qualitative comparison of cells with different origin and possibly different microstructure and processing conditions is always difficult and is insufficient to definitely exclude the hypothesized Ni-YSZ contact loss.

In the present study, the Ni depletion was observed to be more pronounced for higher fuel gas humidities. Increased fuel gas humidity should lead to increased $\mathrm{Ni}(\mathrm{OH})_{\mathrm{x}}$ formation. Thus, the observed trend is in agreement with the hypothesis of $\mathrm{Ni}$ transport via $\mathrm{Ni}(\mathrm{OH})_{\mathrm{x}}$ formation.

Moreover, a correlation of more significant $\mathrm{Ni}$ depletion with increased current densities was observed in the present study. As higher current densities correspond to larger cathodic (Galvani) potential steps, that is, larger overpotentials, Ni particles are more negatively polarized and stronger potential gradients emerge within the porous electrode. According to the hypothesis by Mogensen et al., this should lead to an increasing Ni-Ni contact loss and facilitated formation of volatile $\mathrm{Ni}$ species. Increased current densities also entail higher $p \mathrm{H}_{2} / p \mathrm{H}_{2} \mathrm{O}$ values, generally reducing the activity of $\mathrm{Ni}(\mathrm{OH})_{\mathrm{x}}$. However, due to the small fuel utilization values in the present study $(<20 \%$ for all experiments) and low diffusion resistances of the used cells, this effect is probably limited. According to the hypothesis of Mogensen et al., Ni depletion can be expected to be mainly driven by the potential gradient within the porous electrode. This is consistent with the present results. 
In this study, a similar extent of $\mathrm{Ni}$ depletion was observed for experiments at 800 and $850{ }^{\circ} \mathrm{C}$. However, only little degradation was found at $750{ }^{\circ} \mathrm{C}$, although fuel electrodes at lower temperatures are operated at significantly higher cathodic Galvani potential steps (i.e., larger cathodic overpotentials) and therefore, display larger potential gradients between percolated und non-percolated Ni. However, formation of volatile Ni species is a thermally activated process and according to thermodynamic calculations the vapor pressure of Ni gas species in a $20 \% \mathrm{H}_{2} / 80 \% \mathrm{H}_{2} \mathrm{O}$ fuel gas is lowered by approximately one order of magnitude (from $5 \cdot 10^{-10} \mathrm{~atm}$ to $5 \cdot 10^{-11} \mathrm{~atm}$ ) when the temperature is decreased from 850 to $750{ }^{\circ} \mathrm{C}$.[41] Thus, the high overpotentials at operating temperature of $750{ }^{\circ} \mathrm{C}$ are probably compensated by a general decrease in Ni mobility via volatile gas species, resulting in a stable operating regime where no significant microstructural damage is caused to the fuel electrode.

Thus, the mechanism of Mogensen et al. is in good qualitative agreement with the parameter dependencies observed in the present study, while the lack of non-percolated particles for cells operated under most conditions is remarkable and needs to be investigated further. The observed interplay of the operating parameters humidity, current density and temperature in determining the occurrence and extent of $\mathrm{Ni}$ depletion in the fuel electrode demonstrates the non-linearity of this process and underlines that a more advanced understanding of the occurring process is required to predict the onset of $\mathrm{Ni}$ depletion.

Additionally to the discussed polarization gradient as driving force, there is a temperature gradient through the cell in electrolysis mode due to the heat generation at the fuel electrode's electrochemically active zone. This leads to a change in $\mathrm{Ni}(\mathrm{OH})_{\mathrm{x}}$ activity and, thus, could contribute to Ni transport away from the electrolyte. A rough assessment of the temperature profile can be made based upon the reversible and irreversible heat losses as shown in the following. By using the standard reaction entropy values (at $\left.\frac{p \mathrm{H}_{2}}{p \mathrm{H}_{2} \mathrm{O}}=1\right)$ for fuel electrode $(\Delta \mathrm{s}=$ $\left.67.3 \mathrm{~J} \cdot \mathrm{K}^{-1} \cdot \mathrm{mol}^{-1}\right)$ and oxygen electrode $\left(\Delta \mathrm{s}=-123 \mathrm{~J} \cdot \mathrm{K}^{-1} \cdot \mathrm{mol}^{-1}\right)$ reactions at $800{ }^{\circ} \mathrm{C}$ reported 
in ref.[37,42], the reversible heat consumption can be calculated according to $\dot{Q}_{r e v}=-T \Delta S$. The respective scheme of reversible heat consumption/generation at the electrodes in SOEC mode is depicted in Fig. 10a. Additionally, irreversible losses at the electrodes and at the electrolyte are taken into account as shown for an SOEC at thermo-neutral voltage in Fig. 10b. At thermo-neutral conditions the overall endothermic reversible heat consumption over the cell is compensated by irreversible losses at fuel electrode, electrolyte and oxygen electrode, which in this case corresponds to a total overpotential of $0.31 \mathrm{~V}$. This overpotential is attributed to electrodes and electrolyte proportionally to the magnitude of their initial resistance according to Table 1 .

On the basis of this simplistic consideration of heat generation, it can be deduced that in SOEC mode there will be a temperature gradient from fuel to oxygen electrode and also from the fuel electrode functional layer to the gas channel. This would cause a higher activity of volatile Ni species at the functional layer and could contribute to Ni migration away from the electrode/electrolyte interface. However, to make quantitative statements about the magnitude of this temperature gradient, and thus, a reliably estimate of its effect on Ni migration, the temperature profile in the porous electrode has to be calculated with a more sophisticated method, for example with a non-isothermal model that incorporates all necessary heat transport equations for heat conduction, convection and radiation, as implemented in Ref.[43].

\subsection{Fuel electrode resistance}

While the Ni depletion discussed in the previous section is a fuel electrode degradation process, the process is reflected by an increase in ohmic resistance. The present section will investigate the effect of long-term degradation on the fuel electrode charge transfer resistance, that is, the two high-frequency contributions $\mathrm{P}_{1}$ and $\mathrm{P}_{2}$ identified in Fig. A.3. The interpretation of results is complex since both processes P1 and P2 are coupled, and as a 
consequence different degradation processes related to the fuel electrode resistance are difficult to distinguish.

The change in fuel electrode polarization resistance of all cells is presented in Fig. 11. Each figure contains the information of the total fuel electrode polarization resistance $\left(\mathrm{P}_{1}+\mathrm{P}_{2}\right)$, as well as the individual contributions of $\mathrm{P}_{1}$ and $\mathrm{P}_{2}$. The quantitative separation of these two processes is difficult due to their similar characteristic frequencies caused by the increase of the characteristic frequencies of P2 during operation as will be explained later (compare Fig. 12). Furthermore, it has been demonstrated that the high-frequency fuel electrode processes can be modeled with a transmission line model in a more physically meaningful way than with two R-CPE elements.[20,23] This can result in an uncertainty regarding the determined resistance values of $\mathrm{P}_{1}$ and $\mathrm{P}_{2}$. However, further quantitative information about the electrode's microstructure is required as input parameters to reduce the number of fitting parameter in a transmission line model. Moreover, the high-frequency fuel electrode processes have successfully been modeled with two R-CPE elements in a first approximation before.[44]

For all operating conditions except at $40 \%$ humidity, the resistance increase of the combined fuel electrode process $\mathrm{P}_{1}+\mathrm{P}_{2}$ is significantly lower than the ones of the ohmic resistance depicted in Figure 5. Furthermore, a general trend observed for almost all cells is an initial decrease of $\mathrm{P}_{2}$ within the first $150 \mathrm{~h}$ followed by a comparatively stable behavior for the remaining operation. This behavior is witnessed at all operating conditions, except for the cells operated at the lowest investigated humidity $(40 \% \mathrm{MH})$ and high current densities (1.0 $\mathrm{A} \cdot \mathrm{cm}^{-2}$ and $1.5 \mathrm{~A} \cdot \mathrm{cm}^{-2}$ ), indicating that the reaction overvoltage might be a possible driving factor. These cells show an increase of P2 followed by a decrease.

The initial conditioning of the cells is accompanied by a large shift of the relaxation time especially of the lower frequency fuel electrode process towards higher frequencies, which is illustrated in Fig. 12 by the imaginary impedance plots of cells operated at $800{ }^{\circ} \mathrm{C}$ and 
$80 \% \mathrm{MH}$. While the two peaks related to the fuel electrode process can be distinguished at the initial EIS measurement, they merge into one visible peak after longer testing times. During this conditioning time, the imaginary impedance plots confirm a decrease of the intensity of $\mathrm{P}_{2}$ and an increase of $\mathrm{P}_{1}$ in agreement with the obtained fitting values in Fig. 5. This Ni/YSZ electrode conditioning has not been reported in literature so far. Apart from this initial change no clear correlations concerning the influence of operating parameters on $\mathrm{P}_{2}$ can be identified. Degradation of the fuel electrode mainly originates from an increase in $\mathrm{P}_{1}$. For most conditions, $\mathrm{P}_{1}$ tends to increase with current densities. For cells operated at $80 \% \mathrm{MH}$, degradation is larger at $800{ }^{\circ} \mathrm{C}$ and $850{ }^{\circ} \mathrm{C}$ compared to $750{ }^{\circ} \mathrm{C}$, indicating the detrimental effect of temperature on anode microstructure. No obvious trend with humidity change was observed. Thus, in the present study, the fuel electrode degradation is dominated by an increase of $\mathrm{P}_{1}$, while $\mathrm{P}_{2}$ barely changes.

The increased degradation of $\mathrm{P}_{1}$ at higher temperatures and current densities correlates well with the observed Ni depletion behavior. As seen in the previous section, the longer ionic path in the Ni-depleted electrode leads to an increase of the ohmic resistance, which can be explained by an effective extension of the electrolyte once regions at the interface are fully depleted of Ni. However, the partial removal or loss of percolation of Ni particles without the formation of fully Ni depleted regions would be expected to rather entail an increase of the resistance of the fuel electrode process $\mathrm{P}_{1}$ that contains the coupled ionic conduction and charge transfer since the reaction zone is extended. This is a possible explanation for the observed behavior of $\mathrm{P}_{1}$. This is also consistent with Hauch et al., who have observed the degradation of $\mathrm{P}_{1}$ to be dominant in a Ni/3YSZ electrode and a simultaneous loss of $\mathrm{Ni}$ percolation and depletion at the electrode/electrolyte interface.[12]

An additional explanation for the increasing resistance of $\mathrm{P}_{1}$ could be the decreasing ionic conductivity of the $8 \mathrm{YSZ}$ in the fuel electrode. As a phase change from cubic to tetragonal is the likely explanation, its contribution to the degradation of P1 is expected to occur analogue 
to the increase of the ohmic resistance of cells operated at OCV. Consequently, this contribution to the increase of $\mathrm{P} 1$ is not expected to be dominant, since the degradation of $\mathrm{P} 1$ and the degradation of the ohmic resistance at OCV show opposite temperature dependencies. Since the resistance of $\mathrm{P}_{2}$ does not considerably increase over time, it is concluded that $\mathrm{Ni}$ depletion at the electrode/electrolyte interface does not have a significant influence on the fuel electrode charge transfer resistance. This would imply that the triple phase boundary length density at the reaction zone probably stays constant during the experiment. Pronounced Ni coarsening seems to be unlikely. Recently, it has been shown that the transition of the reaction zone from the functional to the support layer leads to a significant increase in fuel electrode resistance due to slower kinetics.[45] This seems not to be the case in the present study. However, the lack of an increase in P2 for the duration of the experiment does not negate the fact that $\mathrm{Ni}$ is removed from the electrode. If continued, loss of $\mathrm{Ni}$ percolation or partial $\mathrm{Ni}$ removal is expected to change the TPB length density and consequently, should lead to increase of $\mathrm{P}_{2}$.

The present CNLS fitting procedure was guided by the calculation of DRT for all impedance spectra, as frequently done in literature to improve fitting accuracy.[21,22,46] However, uncertainties in the reliable separation of the processes $\mathrm{P}_{1}$ and $\mathrm{P}_{2}$ could still arise due to the non-physical nature of an equivalent circuit model based on R-CPE elements, making a definite deconvolution of the fuel electrode processes difficult. Furthermore, a more detailed understanding of the origins of $\mathrm{P}_{1}$ and $\mathrm{P}_{2}$ and how they are affected by different microstructural parameters is still missing, which makes the interpretation of the present degradation results difficult.

\section{Summary and Conclusions}


The present study provides a detailed understanding of major degradation processes limiting SOEC lifetime. A series of 20 comparable long-term degradation measurements of LSCF $|\mathrm{CGO}|$ YSZ|Ni/YSZ-based fuel electrode supported cells each over $1000 \mathrm{~h}$ systematically elucidates the influence of the operating parameters temperature, fuel gas humidity and current density on the individual degradation processes. Temperature was varied between 750 and $850{ }^{\circ} \mathrm{C}$, humidity between $40 \%$ to $80 \% \mathrm{H}_{2} \mathrm{O}$, and the current density between $\mathrm{OCV}$ and $1.5 \mathrm{~A} \cdot \mathrm{cm}^{-2}$. The present work focuses on the fuel electrode degradation, while degradation of the other cell components will be analyzed in future work. The main fuel electrode degradation process was identified to be Ni depletion. This process was observed to be driven by current density and, thus, was not observed at OCV. Furthermore, the process was only witnessed to be significant for humidities of $80 \%$ and temperatures of $800{ }^{\circ} \mathrm{C}$ and above, respectively. Ni-depleted layers were observed to form by means of low-voltage SEM at the electrode/electrolyte interface and lead to an effective increase of the electrolyte thickness due to emergence of a porous YSZ layer. This is also reflected by an increasing ohmic resistance in the electrochemical impedance spectra, which correlates quantitatively well with the observed thickness of the Ni depleted layer. The underlying mechanism was proposed to be related to $\mathrm{Ni}$ transport via volatile $\mathrm{Ni}(\mathrm{OH})_{\mathrm{x}}$ species, following the gradient of $\mathrm{Ni}(\mathrm{OH})_{\mathrm{x}}$ activity from non-percolated to percolated $\mathrm{Ni}$ under cathodic polarization, while a possible contribution of the temperature profile through the cell is discussed. Furthermore, the fuel electrode charge transfer resistance predominantly exhibits degradation in the highfrequency region around $10^{4} \mathrm{~Hz}$. This suggests the underlying mechanism being either related to an extension of the reaction zone, due to a partial loss of Ni contact or to a reduction of ionic conductivity in the YSZ backbone rather than a change of the actual charge transfer reaction. 


\section{Acknowledgements}

Financial support from the Helmholtz Association in the frame of the Helmholtz Energy Alliance "Stationary electrochemical solid state storage and conversion" is gratefully acknowledged. The authors would like to thank Ina Plock for help with SEM imaging. 


\section{References}

[1] R. Knibbe, A. Hauch, J. Hjelm, S.D. Ebbesen, M. Mogensen, Durability of solid oxide cells, Green. 1 (2011) 141-169. doi:10.1515/GREEN.2011.015.

[2] S.D. Ebbesen, M. Mogensen, Electrolysis of carbon dioxide in Solid Oxide Electrolysis Cells, J. Power Sources. 193 (2009) 349-358. doi:10.1016/j.jpowsour.2009.02.093.

[3] A. Hauch, J.R. Bowen, L.T. Kuhn, M. Mogensen, Nanoscale Chemical Analysis and Imaging of Solid Oxide Cells, Electrochem. Solid-State Lett. 11 (2008) B38-B41. doi:10.1149/1.2828845.

[4] K.V. Hansen, K. Norrman, M. Mogensen, H2-H2O-Ni-YSZ Electrode Performance, J. Electrochem. Soc. 151 (2004) A1436-A1444. doi:10.1149/1.1779630.

[5] A. Hauch, S.H. Jensen, S. Ramousse, M. Mogensen, Performance and Durability of Solid Oxide Electrolysis Cells, J. Electrochem. Soc. 153 (2006) A1741. doi:10.1149/1.2216562.

[6] L. Holzer, B. Iwanschitz, T. Hocker, B. Münch, M. Prestat, D. Wiedenmann, U. Vogt, P. Holtappels, J. Sfeir, A. Mai, T. Graule, Microstructure degradation of cermet anodes for solid oxide fuel cells: Quantification of nickel grain growth in dry and in humid atmospheres, J. Power Sources. $196 \quad$ (2011) 1279-1294. doi:10.1016/j.jpowsour.2010.08.017.

[7] A. Hauch, S.D. Ebbesen, S.H. Jensen, M. Mogensen, Solid Oxide Electrolysis Cells: Microstructure and Degradation of the Ni/Yttria-Stabilized Zirconia Electrode, J. Electrochem. Soc. 155 (2008) B1184-B1193. doi:10.1149/1.2967331.

[8] D.A. Osinkin, B.L. Kuzin, N.M. Bogdanovich, Effect of oxygen activity and water partial pressure to degradation rate of $\mathrm{Ni}$ cermet electrode contacting Zr0.84Y0.16O1.92 electrolyte, Russ. J. Electrochem. 46 (2010) 41-48. doi:https://doi.org/10.1134/S1023193510010052.

[9] A. Hauch, M. Mogensen, A. Hagen, Ni/YSZ electrode degradation studied by impedance spectroscopy - Effect of p(H2O), Solid State Ionics. 192 (2011) 547-551. doi:10.1016/j.ssi.2010.01.004.

[10] M.B. Mogensen, A. Hauch, X. Sun, M. Chen, Y. Tao, S.D. Ebbesen, K. V. Hansen, P. V. Hendriksen, Relation Between Ni Particle Shape Change and Ni Migration in NiYSZ Electrodes - a Hypothesis, Fuel Cells. 17 (2017) 434-441. doi:10.1002/fuce.201600222.

[11] F. Tietz, D. Sebold, A. Brisse, J. Schefold, Degradation phenomena in a solid oxide electrolysis cell after $9000 \mathrm{~h}$ of operation, J. Power Sources. 223 (2013) 129-135. doi:10.1016/j.jpowsour.2012.09.061.

[12] A. Hauch, K. Brodersen, M. Chen, M.B. Mogensen, Ni / YSZ electrodes structures optimized for increased electrolysis performance and durability, Solid State Ionics. 293 (2016) 27-36. doi:10.1016/j.ssi.2016.06.003.

[13] M. Chen, Y.-L. Liu, J.J. Bentzen, W. Zhang, X. Sun, A. Hauch, Y. Tao, J.R. Bowen, P. V Hendriksen, Microstructural Degradation of Ni/YSZ Electrodes in Solid Oxide Electrolysis Cells under High Current, J. Electrochem. Soc. 160 (2013) F883-F891. doi:10.1149/2.098308jes.

[14] A. Hauch, A. Hagen, J. Hjelm, T. Ramos, Sulfur Poisoning of SOFC Anodes: Effect of Overpotential on Long-Term Degradation, J. Electrochem. Soc. 161 (2014) F734F743. doi:10.1149/2.080406jes.

[15] M. Riegraf, A. Zekri, M. Knipper, R. Costa, G. Schiller, K.A. Friedrich, Sulfur Poisoning of Ni/Gadolinium-Doped Ceria Anodes: A Long-Term Study Outlining Stable Solid Oxide Fuel Cell Operation, J. Power Sources. (2017) submitted.

[16] M. Riegraf, V. Yurkiv, R. Costa, G. Schiller, K.A. Friedrich, Evaluation of the Effect 
of Sulfur on the Performance of Nickel/Gadolinium-Doped Ceria Based Solid Oxide Fuel Cell Anodes, ChemSusChem. 10 (2017) 587-599. doi:10.1002/cssc.201601320.

[17] M. Riegraf, M. Hoerlein, R. Costa, G. Schiller, K.A. Friedrich, Sulfur Poisoning of Electrochemical Reformate Conversion on Ni/Gadolinium-Doped Ceria Electrodes, ACS Catal. 7 (2017) 7760-7771. doi:10.1021/acscatal.7b02177.

[18] S. Risse, N.A. Cañas, N. Wagner, E. Härk, M. Ballauff, K.A. Friedrich, Correlation of capacity fading processes and electrochemical impedance spectra in lithium/sulfur cells, J. Power Sources. 323 (2016) 107-114. doi:10.1016/j.jpowsour.2016.05.032.

[19] K. Thydén, Y.L. Liu, J.B. Bilde-Sørensen, Microstructural characterization of SOFC Ni-YSZ anode composites by low-voltage scanning electron microscopy, Solid State Ionics. 178 (2008) 1984-1989. doi:10.1016/j.ssi.2007.12.075.

[20] V. Sonn, A. Leonide, E. Ivers-Tiffée, Combined Deconvolution and CNLS Fitting Approach Applied on the Impedance Response of Technical Ni8YSZ Cermet Electrodes, J. Electrochem. Soc. 155 (2008) B675-B679. doi:10.1149/1.2908860.

[21] A. Leonide, V. Sonn, A. Weber, E. Ivers-Tiffée, Evaluation and Modeling of the Cell Resistance in Anode-Supported Solid Oxide Fuel Cells, J. Electrochem. Soc. 155 (2008) B36-B41. doi:10.1149/1.2801372.

[22] A. Leonide, Y. Apel, E. Ivers-Tiffee, SOFC Modeling and Parameter Identification by Means of Impedance Spectroscopy, ECS Trans. 19(20) (2009) 81-109. doi:10.1149/1.3247567.

[23] B.A. Boukamp, M. Verbraeken, D.H.A. Blank, P. Holtappels, SOFC-anodes, proof for a finite-length type Gerischer impedance?, Solid State Ionics. 177 (2006) 2539-2541. doi:10.1016/j.ssi.2006.03.002.

[24] R. Barfod, M. Mogensen, T. Klemenso, A. Hagen, Y.-L. Liu, P. Vang Hendriksen, Detailed Characterization of Anode-Supported SOFCs by Impedance Spectroscopy, J. Electrochem. Soc. 154 (2007) B371-B378. doi:10.1149/1.2433311.

[25] S.B. Adler, X.Y. Chen, J.R. Wilson, Mechanisms and rate laws for oxygen exchange on mixed-conducting oxide surfaces, J. Catal. 245 (2007) 91-109. doi:10.1016/j.jcat.2006.09.019.

[26] S.B. Adler, Factors governing oxygen reduction in solid oxide fuel cell cathodes, Chem. Rev. 104 (2004) 4791-4843. doi:10.1021/cr020724o.

[27] B.A. Boukamp, H.J.M. Bouwmeester, Interpretation of the Gerischer impedance in solid state ionics, Solid State Ionics. 157 (2003) 29-33. doi:10.1016/S01672738(02)00185-6.

[28] P. Moçoteguy, A. Brisse, A review and comprehensive analysis of degradation mechanisms of solid oxide electrolysis cells, Int. J. Hydrogen Energy. 38 (2013) 15887-15902. doi:10.1016/j.ijhydene.2013.09.045.

[29] J.W. Fergus, Electrolytes for solid oxide fuel cells, J. Power Sources. 162 (2006) 3040. doi:https://doi.org/10.1016/j.jpowsour.2006.06.062.

[30] P. Hjalmarsson, X. Sun, Y.L. Liu, M. Chen, Influence of the oxygen electrode and inter-diffusion barrier on the degradation of solid oxide electrolysis cells, J. Power Sources. 223 (2013) 349-357. doi:10.1016/j.jpowsour.2012.08.063.

[31] J.R. Mawdsley, J. David Carter, A. Jeremy Kropf, B. Yildiz, V.A. Maroni, Post-test evaluation of oxygen electrodes from solid oxide electrolysis stacks, Int. J. Hydrogen Energy. 34 (2009) 4198-4207. doi:10.1016/j.ijhydene.2008.07.061.

[32] M.A. Laguna-Bercero, R. Campana, A. Larrea, J.A. Kilner, V.M. Orera, Electrolyte degradation in anode supported microtubular yttria stabilized zirconia-based solid oxide steam electrolysis cells at high voltages of operation, J. Power Sources. 196 (2011) 8942-8947. doi:10.1016/j.jpowsour.2011.01.015.

[33] J.S. Herring, J.E. O’Brien, C.M. Stoots, G.L. Hawkes, J.J. Hartvigsen, M. Shahnam, Progress in high-temperature electrolysis for hydrogen production using planar SOFC 
technology, Int. J. Hydrogen Energy. $32 \quad$ (2007) 440-450. doi:10.1016/j.ijhydene.2006.06.061.

[34] Anil V. Virkar, Mechanism of oxygen electrode delamination in solid oxide electrolyzer cells, Int. J. Hydrogen Energy. 35 (2010) 9527-9543. doi:https://doi.org/10.1016/j.ijhydene.2010.06.058.

[35] M. Vogler, A. Bieberle-Hütter, L. Gauckler, J. Warnatz, W.G. Bessler, Modelling Study of Surface Reactions, Diffusion, and Spillover at a Ni/YSZ Patterned Anode, J. Electrochem. Soc. 156 (2009) B663-B672. doi:10.1149/1.3095477.

[36] W.G. Bessler, M. Vogler, H. Störmer, D. Gerthsen, A. Utz, E. Ivers-Tiffeé, Model anodes and anode models for understanding the mechanism of hydrogen oxidation in solid oxide fuel cells, Phys. Chem. Chem. Phys. 12 (2010) 13888-13903. doi:10.1039/c0cp00541j.

[37] M. Riegraf, G. Schiller, R. Costa, K.A. Friedrich, A. Latz, V. Yurkiv, Elementary Kinetic Numerical Simulation of Ni/YSZ SOFC Anode Performance Considering Sulfur Poisoning, J. Electrochem. Soc. $162 \quad$ (2014) F65-F75. doi:10.1149/2.0471501jes.

[38] J. Joos, M. Ender, I. Rotscholl, N.H. Menzler, E. Ivers-Tiffée, Quantification of double-layer Ni/YSZ fuel cell anodes from focused ion beam tomography data, J. Power Sources. 246 (2014) 819-830. doi:10.1016/j.jpowsour.2013.08.021.

[39] P. Von Dollen, S. Barnett, A study of screen printed yttria-stabilized zirconia layers for solid oxide fuel cells, J. Am. Ceram. Soc. 88 (2005) 3361-3368. doi:10.1111/j.15512916.2005.00625.x.

[40] J. Liu, S.A. Barnett, Thin Yttrium-Stabilized Zirconia Electrolyte Solid Oxide Fuel Cells by Centrifugal Casting, J. Am. Ceram. Soc. 85 (2002) 3096-3098. doi:10.1111/j.1151-2916.2002.tb00588.x.

[41] M.H. Pihlatie, A. Kaiser, M. Mogensen, M. Chen, Electrical conductivity of Ni-YSZ composites: Degradation due to Ni particle growth, Solid State Ionics. 189 (2011) 8290. doi:10.1016/j.ssi.2011.02.001.

[42] W. Bessler, J. Warnatz, D. Goodwin, The influence of equilibrium potential on the hydrogen oxidation kinetics of SOFC anodes, Solid State Ionics. 177 (2007) 33713383. doi:10.1016/j.ssi.2006.10.020.

[43] N. Russner, H. Geisler, S. Dierickx, A. Weber, E. Ivers-Tiffée, A Non-Isothermal 2D Stationary FEM Model for Hydrocarbon Fueled SOFCs Stack Layers, ECS Trans. 78(1) (2017) 2673-2682. doi:10.13811/j.cnki.eer.2017.01.009.

[44] A. Kromp, S. Dierickx, A. Leonide, A. Weber, E. Ivers-Tiffée, Electrochemical Analysis of Sulfur-Poisoning in Anode Supported SOFCs Fuelled with a Model Reformate, J. Electrochem. Soc. 159 (2012) B597-B601. doi:10.1149/2.015206jes.

[45] S. Dierickx, T. Mundloch, A. Weber, E. Ivers-Tiffée, How Sulfur Tolerance of TwoLayered Ni/YSZ Anodes is Governed by Variations in Microstructure and Thickness, ECS Trans. 78(1) (2017) 1273-1284. doi:10.1149/07801.1273ecst.

[46] A. Kromp, A. Leonide, A. Weber, E. Ivers-Tiffée, Electrochemical Analysis of Reformate-Fuelled Anode Supported SOFC, J. Electrochem. Soc. 158 (2011) B980B989. doi:10.1149/1.3597177.

[47] M.W. Chase, NIST-JANAF Thermochemical Tables, J. Phys. Chem. Ref. Data Monogr. No. 9. (1998) 1-1951. 


\section{Figures}

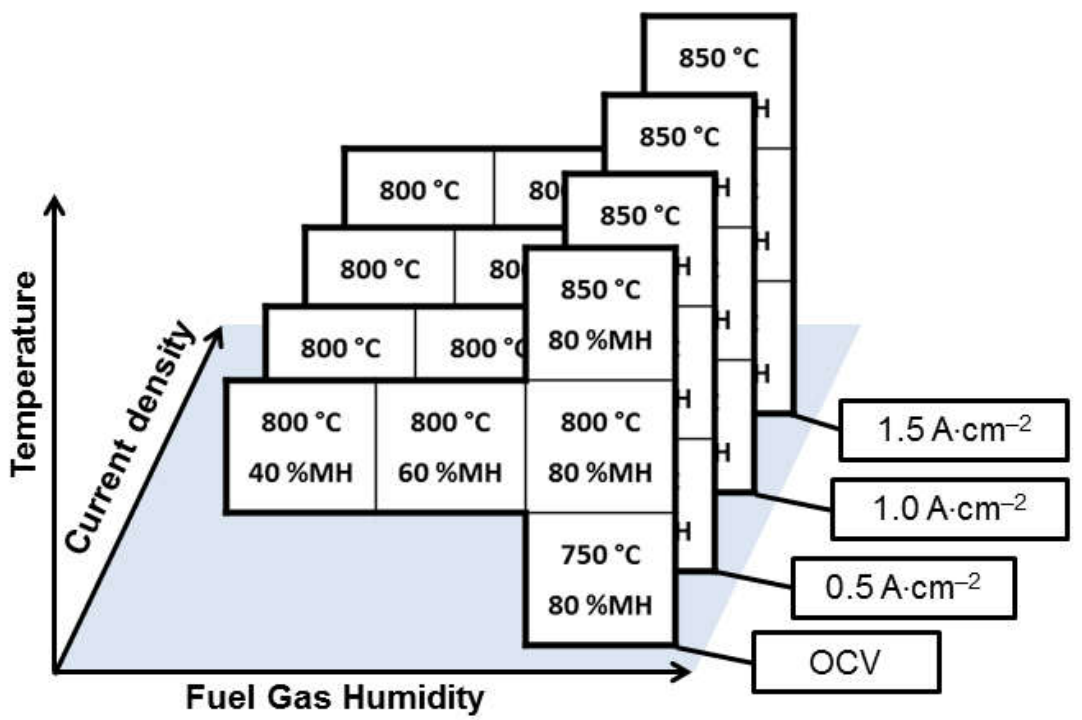

Fig. 1. Testing matrix of the present study consisting of three temperatures, three molar humidites and four current densities devised to separately identify the influence of each investigated parameter on cell degradation in SOEC operation. At each displayed operating condition a long-term experiment over a duration of $1000 \mathrm{~h}$ was conducted. 


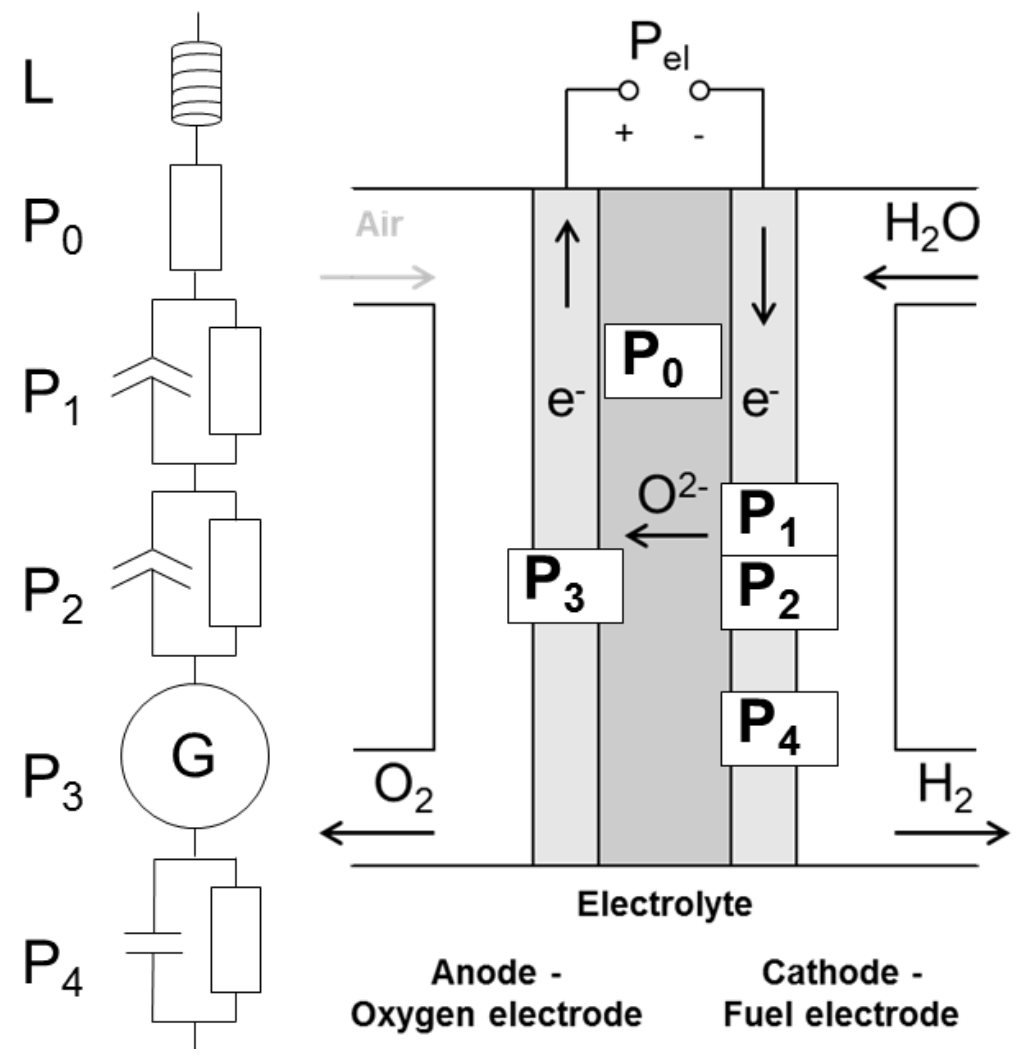

Fig. 2. Equivalent circuit model (left) used for the analysis and separation of the different contributions in the impedance spectra. Additionally, the location of the different processes is depicted on the right. The origin of the contributions is further explained in Table 1.

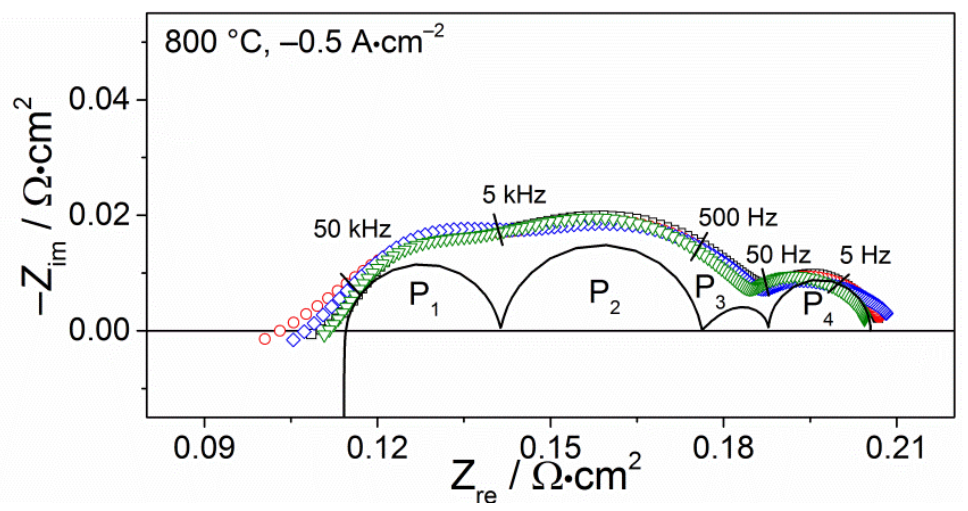

Fig. 3. Induction corrected EIS of four cells in their initial state recorded at $800{ }^{\circ} \mathrm{C}, 60 \% \mathrm{MH}$ and $-0.5 \mathrm{~A} \cdot \mathrm{cm}^{-2}$, visualizing their reproducibility. Contributions of separable rate limiting processes are visualized. The processes correspond to the ones reported in Fig. 2 and Table 1. 

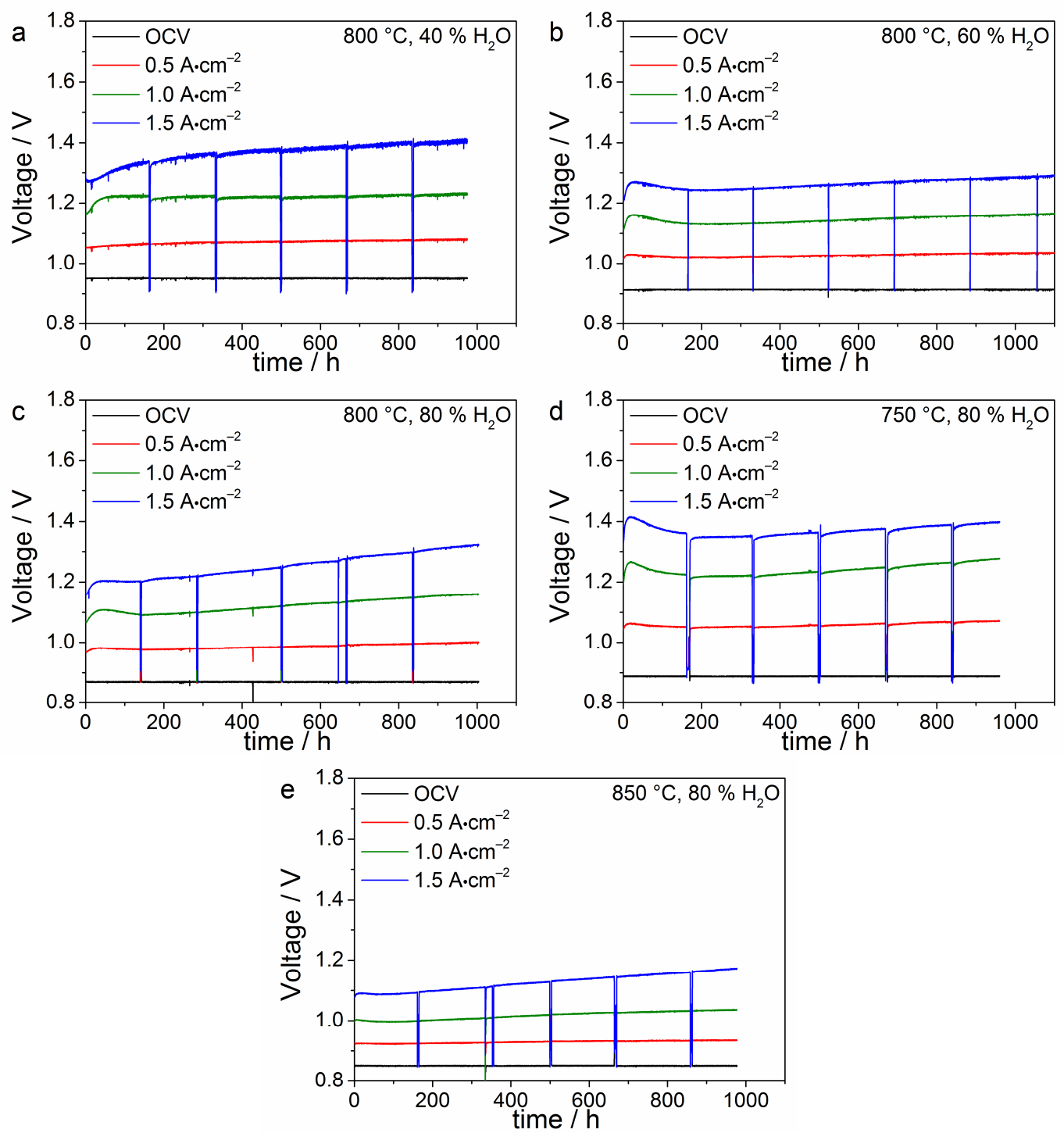

Fig. 4. Voltage evolution over time for cells operated at different current densities and (a) $800{ }^{\circ} \mathrm{C}$ and $40 \% \mathrm{MH}$, (b) $800{ }^{\circ} \mathrm{C}$ and $60 \% \mathrm{MH}$, (c) $800{ }^{\circ} \mathrm{C}$ and $80 \% \mathrm{MH}$, (d) $750{ }^{\circ} \mathrm{C}$ and $80 \% \mathrm{MH}$, and (e) $850{ }^{\circ} \mathrm{C}$ and $80 \% \mathrm{MH}$. 

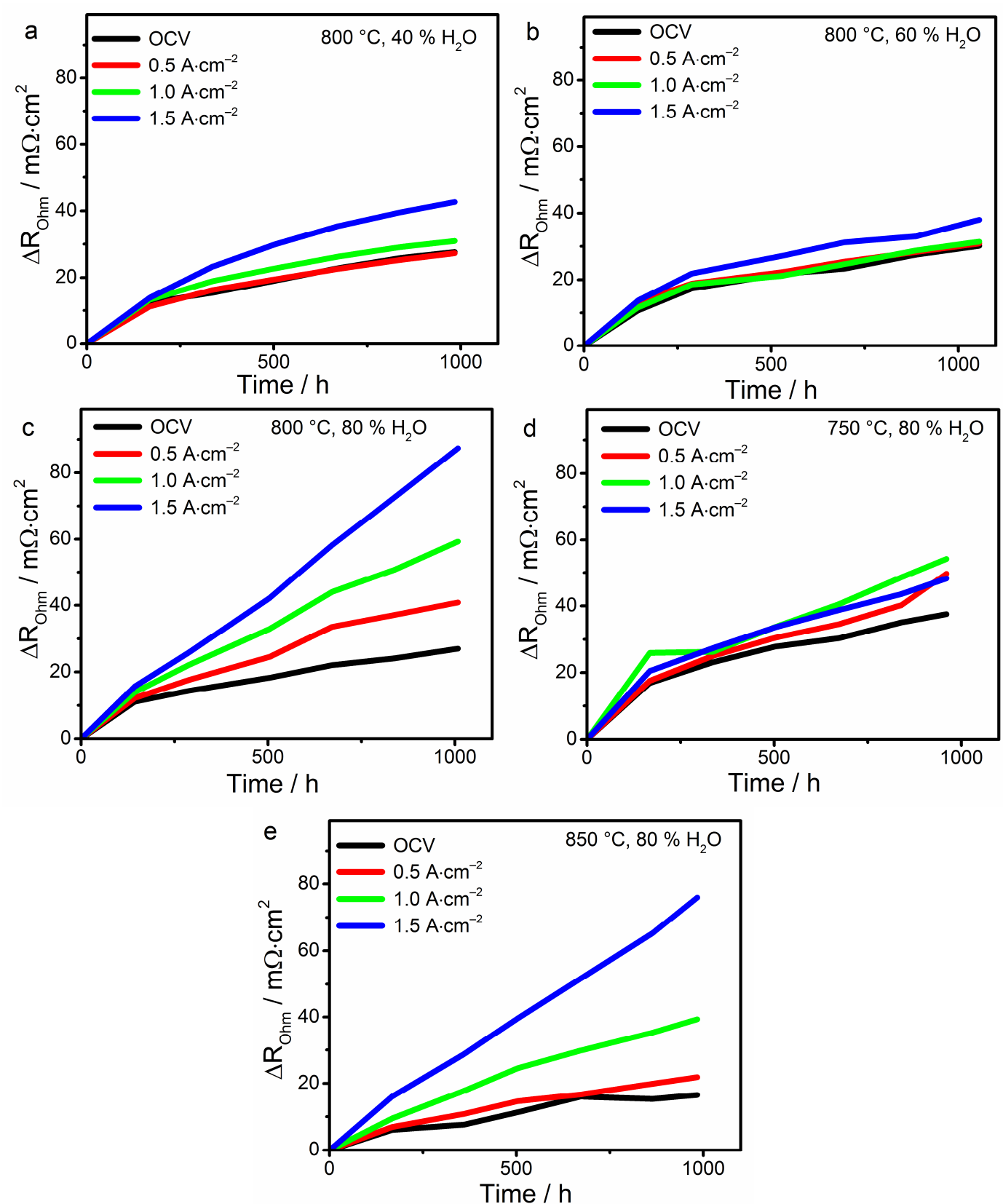

Fig. 5. Change in ohmic resistance of the cells operated at different current densities and (a) $800{ }^{\circ} \mathrm{C}$ and $40 \% \mathrm{MH}$, (b) $800{ }^{\circ} \mathrm{C}$ and $60 \% \mathrm{MH}$, (c) $800{ }^{\circ} \mathrm{C}$ and $80 \% \mathrm{MH}$, (d) $750{ }^{\circ} \mathrm{C}$ and $80 \% \mathrm{MH}$, and (e) $850^{\circ} \mathrm{C}$ and $80 \% \mathrm{MH}$. 


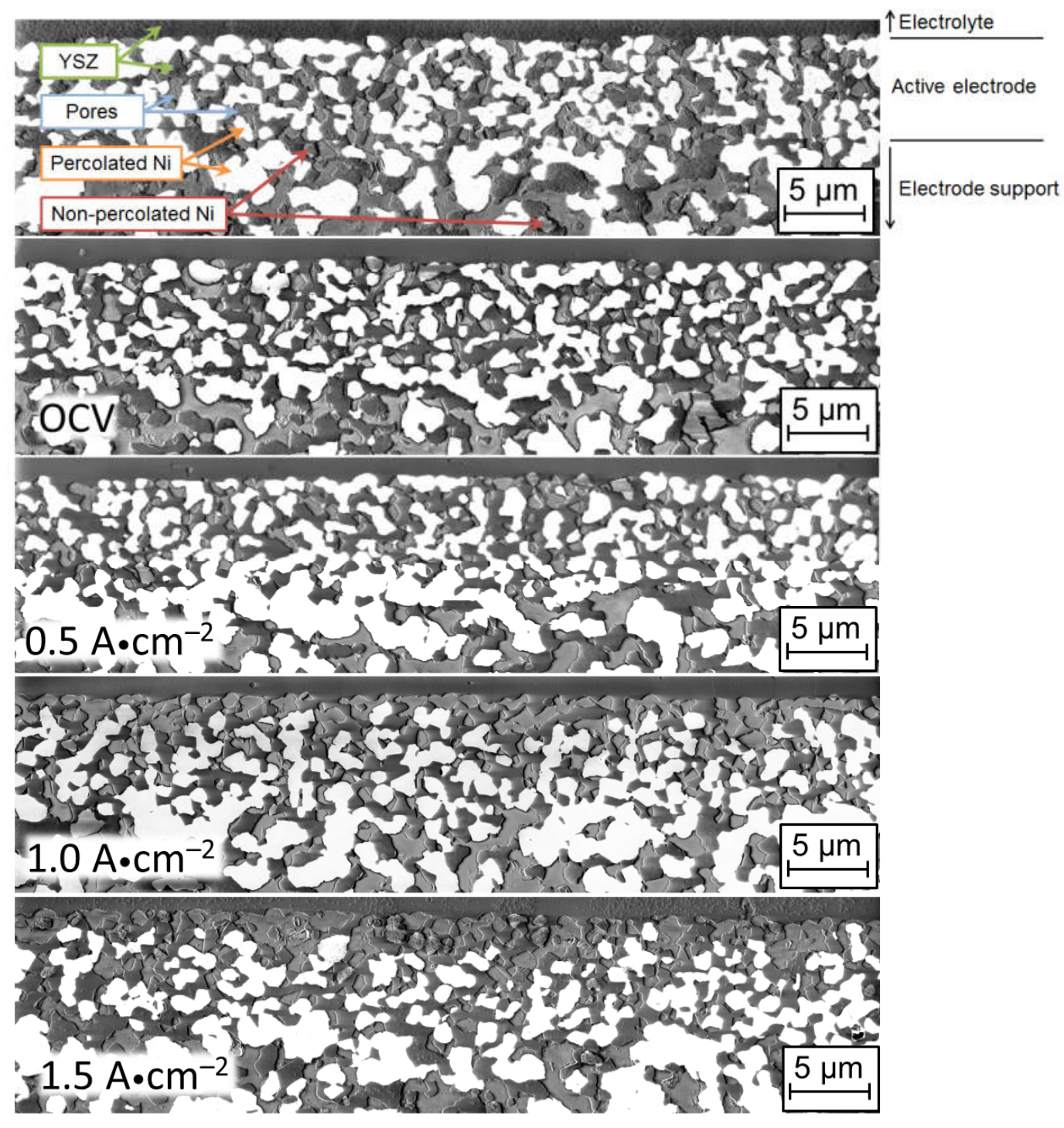

Fig. 6. SEM images of the electrolyte/fuel electrode interface of a reduced reference cell and four cells operated for $1000 \mathrm{~h}$ at $800{ }^{\circ} \mathrm{C}, 80 \% \mathrm{MH}$ and $\mathrm{OCV}, 0.5,1.0$ and $1.5 \mathrm{~A} \cdot \mathrm{cm}^{-2}$. 


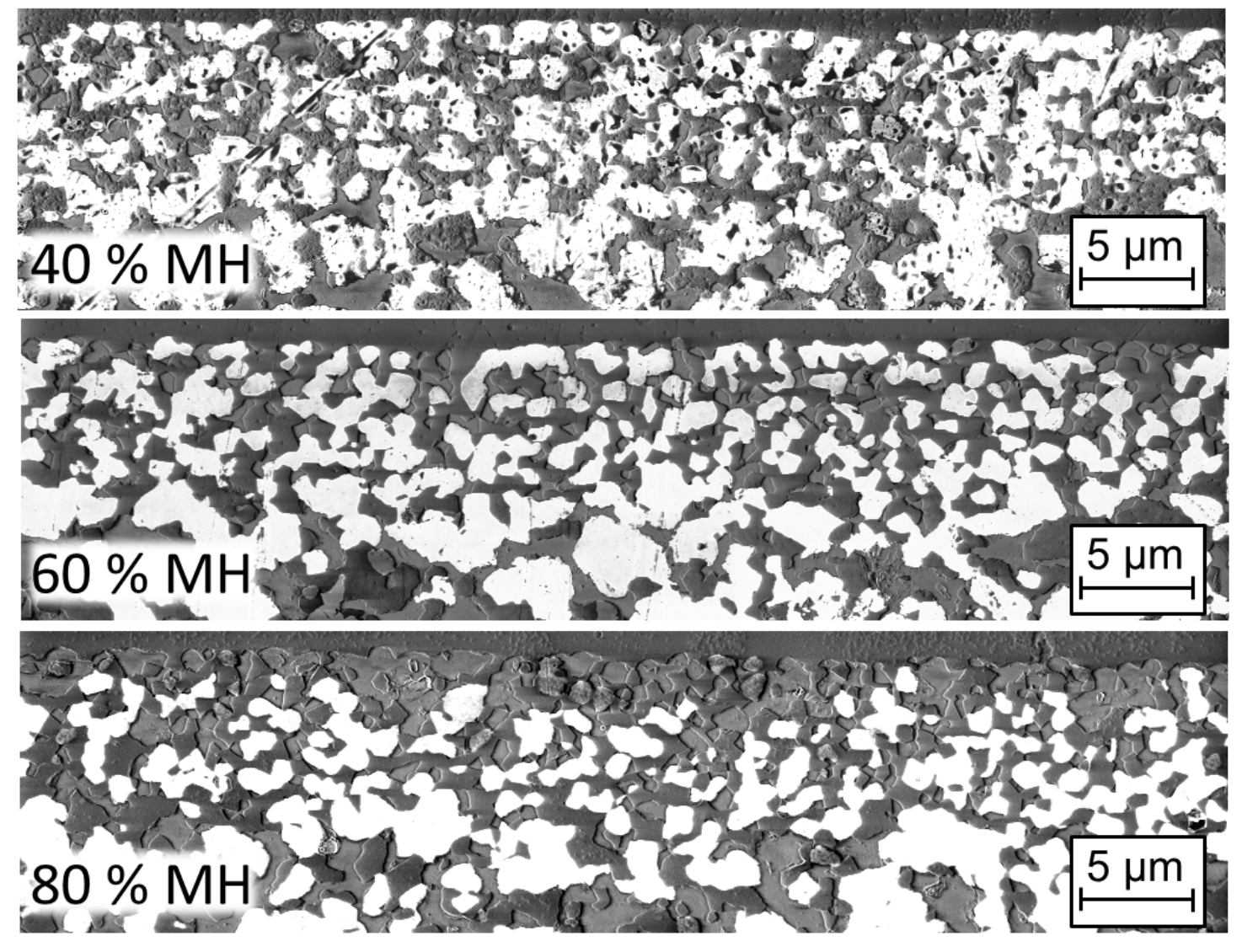

Fig. 7. SEM images of the SEM images operated for $1000 \mathrm{~h}$ at $1.5 \mathrm{~A} \cdot \mathrm{cm}^{-2}, 800{ }^{\circ} \mathrm{C}$, and 40 , 60 , and $80 \% \mathrm{MH}$. Dark spots in the percolated Ni phase of the $40 \% \mathrm{MH}$ sample were caused by problems during sample preparation. 


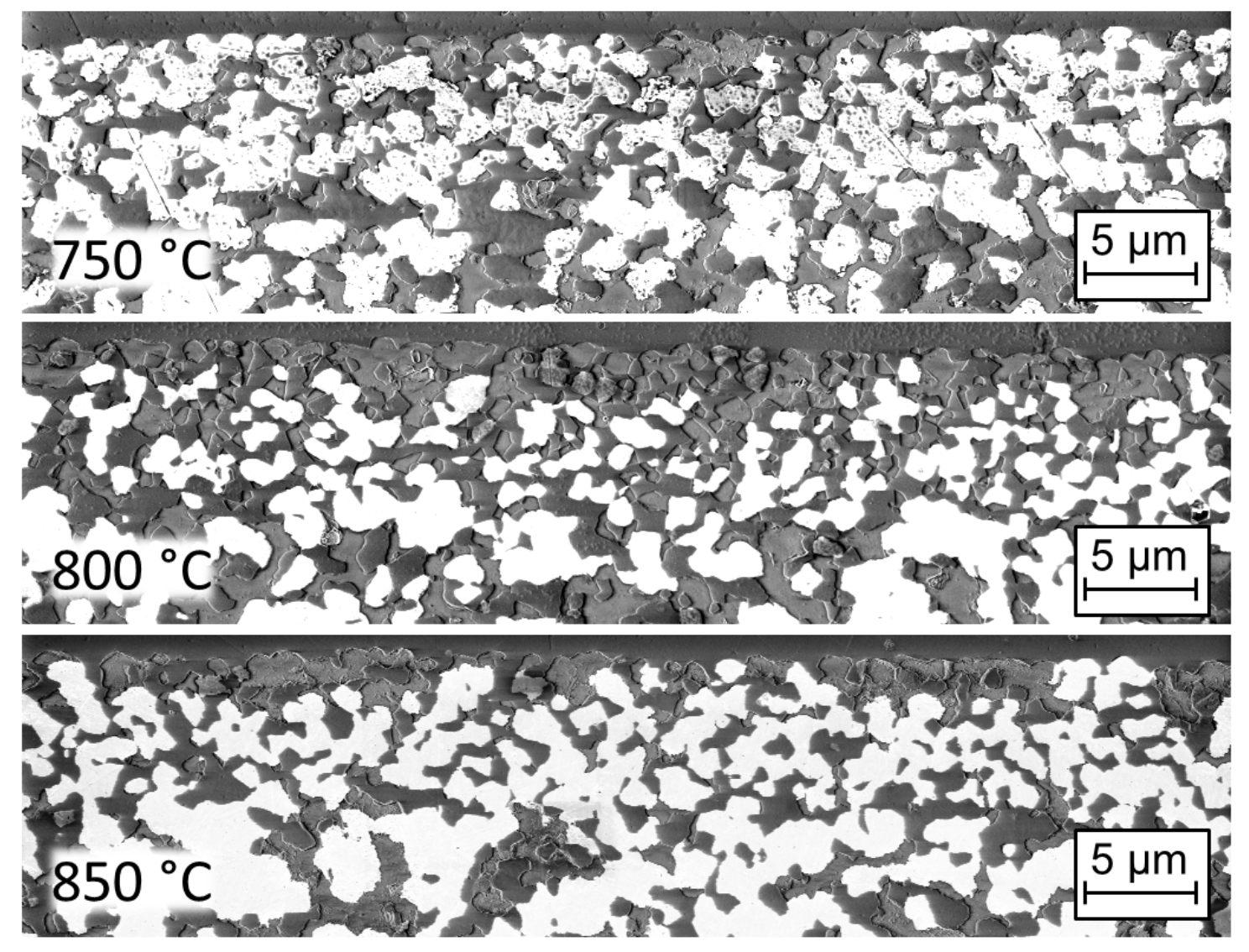

Fig. 8. SEM images of the electrolyte/fuel electrode interface of cells operated for $1000 \mathrm{~h}$ at $1.5 \mathrm{~A} \cdot \mathrm{cm}^{-2}, 80 \% \mathrm{MH}$ and $T=750,800$, and $850{ }^{\circ} \mathrm{C}$. 

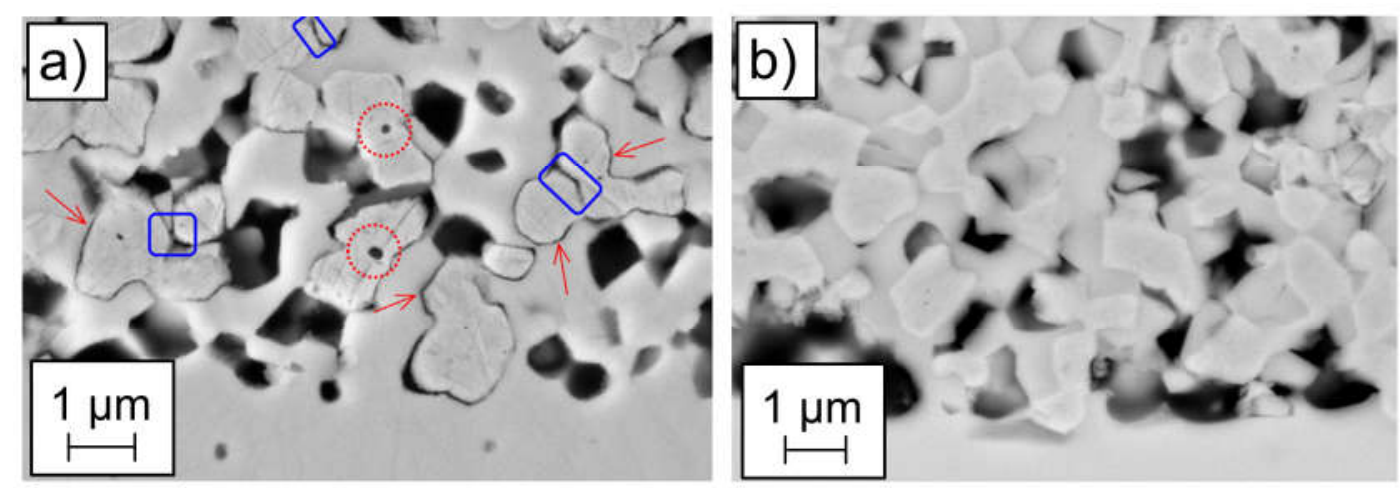

Fig. 9. Comparison of SEM images of the fuel electrode functional layer of two cells operated in SOEC mode. (a) shows a SEM image of an ASC (LSCF|CGO|YSZ|Ni/8YSZ) taken from literature and was operated for $1000 \mathrm{~h}$ at $800^{\circ} \mathrm{C}, 1.25 \mathrm{~A} \cdot \mathrm{cm}^{-2}$ and $90 \% \mathrm{H}_{2} \mathrm{O} / 10 \% \mathrm{H}_{2} \cdot[12]$ (b) shows a SEM image recorded in the present study of a similar ASC that was operated $1000 \mathrm{~h}$ at $800{ }^{\circ} \mathrm{C}, 1.5 \mathrm{~A} \cdot \mathrm{cm}^{-2}$ and $80 \% \mathrm{H}_{2} \mathrm{O} / 20 \% \mathrm{H}_{2}$. In (a) a clear loss of contact between $\mathrm{Ni}$ and YSZ particles is indicated by the red arrows. (b) does not show this gap formation, neither do not any other cells in the present study. 

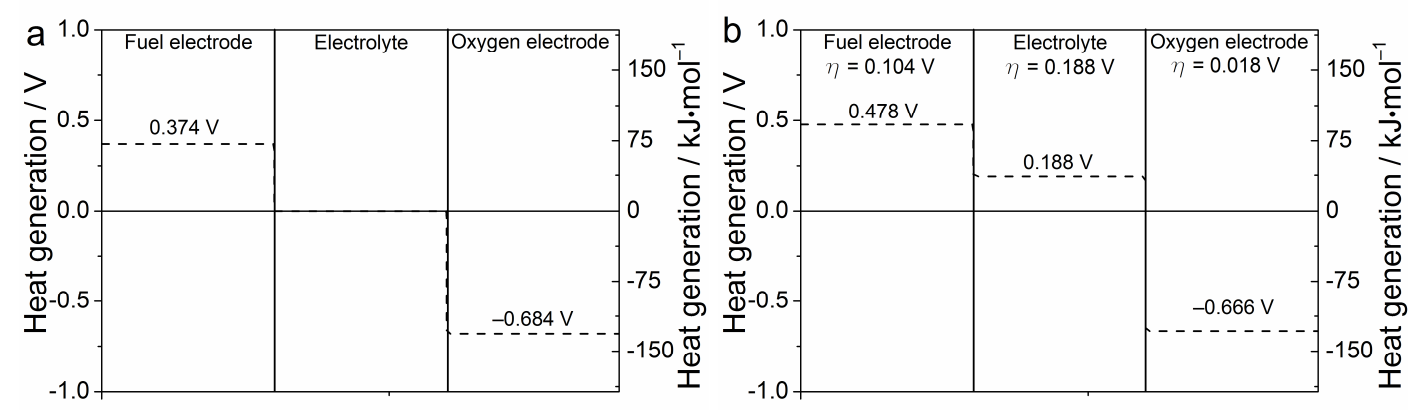

Fig. 10. Schematic depiction of local heat generation (positive values) and consumption (negative) in SOEC mode. (a) Local heat generation for a cell with ideally non-polarizable electrodes calculated based on thermodynamic values at $800{ }^{\circ} \mathrm{C}$ calculated by means of NASA polynomials[47] (gas phase species) and taken from Ref.[42] (surface and bulk species). (b) Local heat generation for a cell at thermo-neutral conditions (sum of heat source and sink terms $=0$ ), with reversible heat generation/consumption from (a) and irreversible terms at fuel electrode $(\mathrm{P} 1+\mathrm{P} 2)$, electrolyte $(\mathrm{P} 0)$ and oxygen electrode $(\mathrm{P} 3)$ estimated based on initial resistance values in Table 1. Heat generation based on mass transport is assumed to be negligible. 
a $\underline{800{ }^{\circ} \mathrm{C}, 40 \% \mathrm{H}_{2}}$ 으
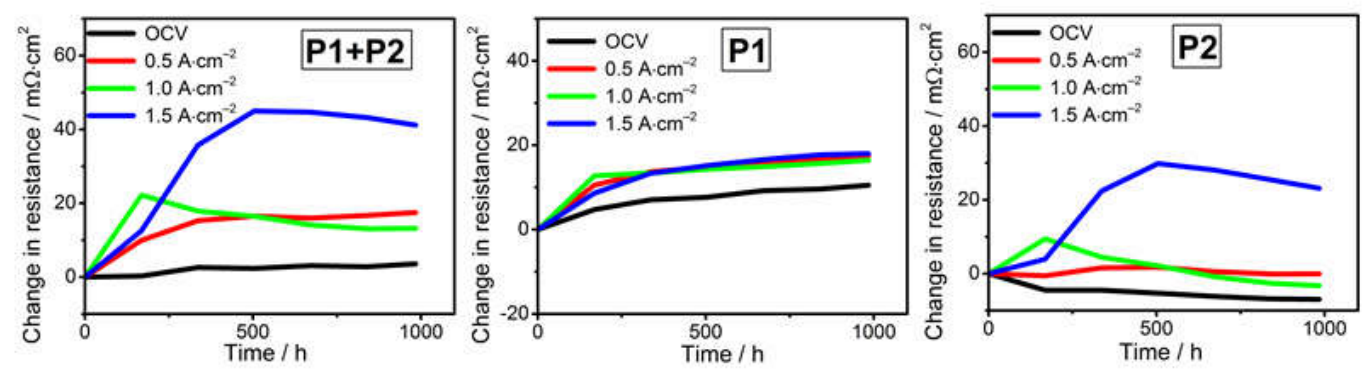

b $800{ }^{\circ} \mathrm{C}, 60 \% \mathrm{H}_{2}$ 으
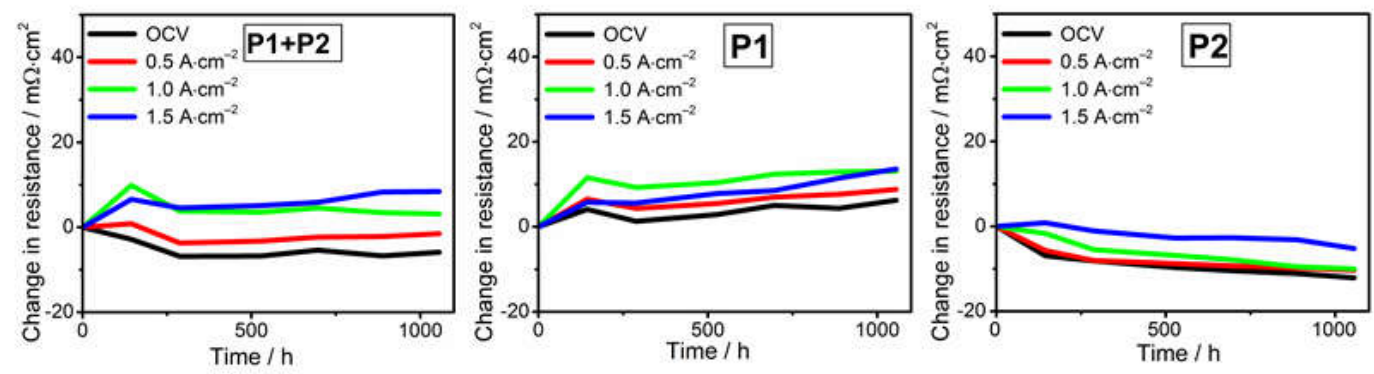

C $800^{\circ} \mathrm{C}, 80 \% \mathrm{H}_{2} \mathrm{O}$
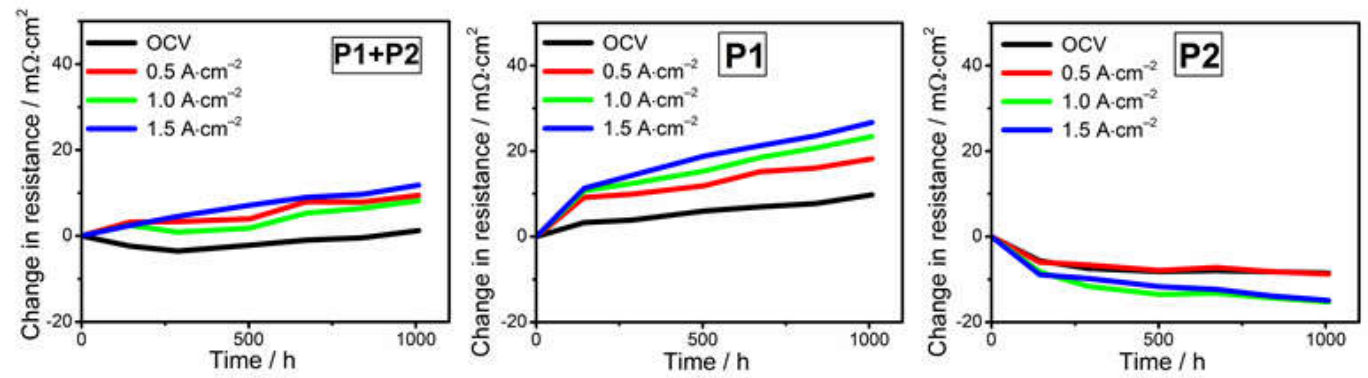

d $\underline{750{ }^{\circ} \mathrm{C}, 80 \% \mathrm{H}_{2}}$ O
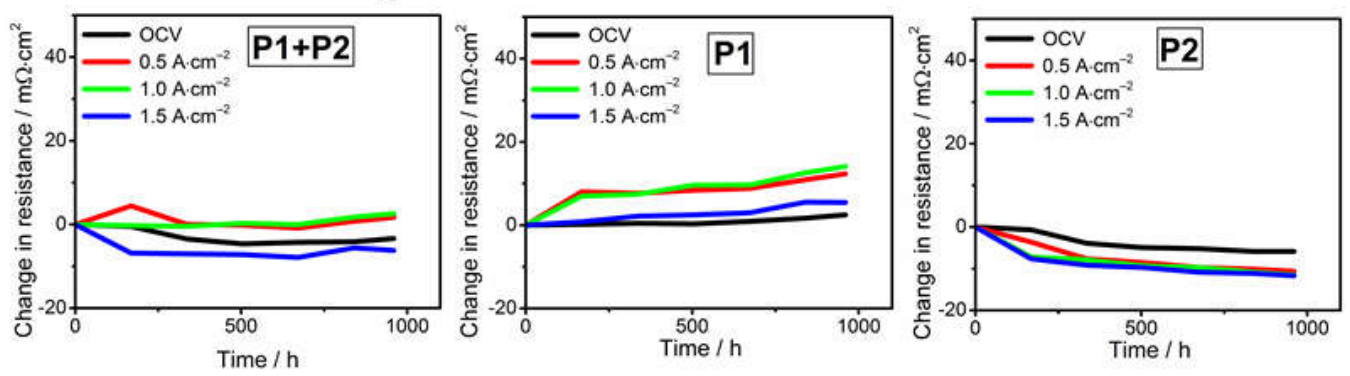

e $850{ }^{\circ} \mathrm{C}, 80 \% \mathrm{H}_{2}$ 으
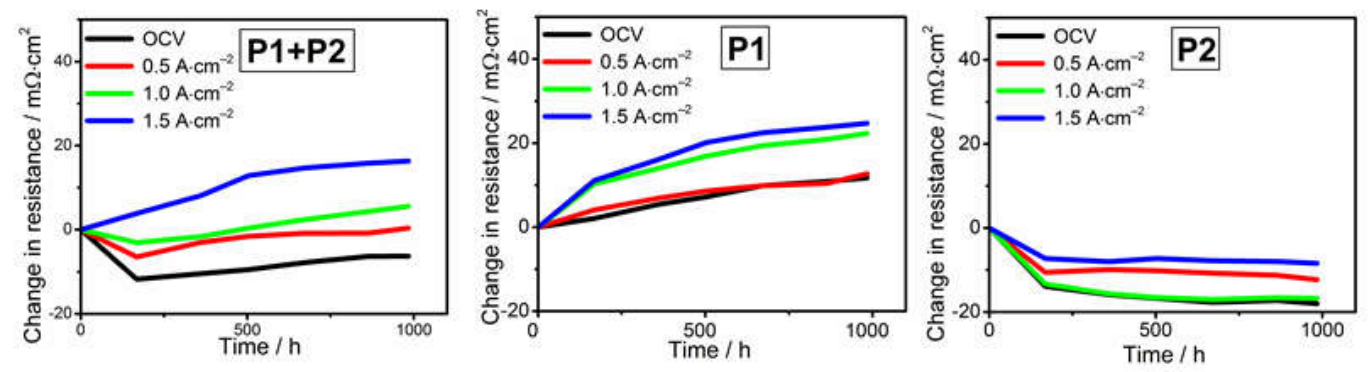
Fig. 11. Change in fuel electrode resistance of the cells operated at (a) $800{ }^{\circ} \mathrm{C}$ and $40 \% \mathrm{MH}$, (b) $800{ }^{\circ} \mathrm{C}$ and $60 \% \mathrm{MH}$, (c) $800{ }^{\circ} \mathrm{C}$ and $80 \% \mathrm{MH}$, (d) $750{ }^{\circ} \mathrm{C}$ and $80 \% \mathrm{MH}$, and (e) $850{ }^{\circ} \mathrm{C}$ and $80 \% \mathrm{MH}$. The graphs show the increase in total fuel electrode resistance $\mathrm{P}_{1}+\mathrm{P}_{2}$ in the left panel and the increase of the individual contributions $\mathrm{P}_{1}$ and $\mathrm{P}_{2}$ in the right panel. 

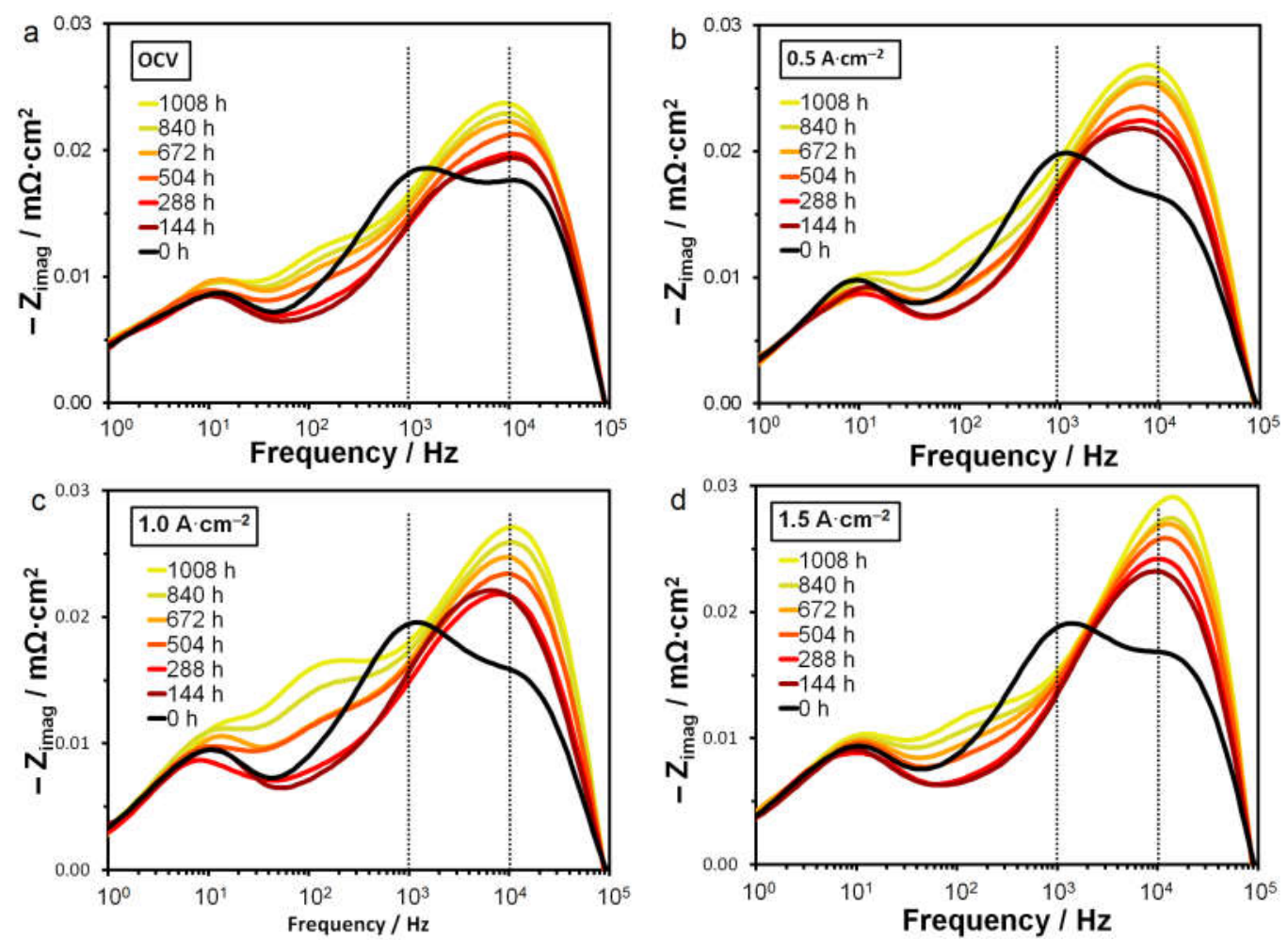

Fig. 12. Imaginary impedance plots of cells operated at $800{ }^{\circ} \mathrm{C}, 80 \% \mathrm{MH}$ and (a) OCV, (b) 0.5 , (c) 1.0 and (d) $1.5 \mathrm{~A} \cdot \mathrm{cm}^{-2}$, displaying the EIS characteristics during $1000 \mathrm{~h}$ of operation. 